\title{
TOTAL STRUCTURE OF THE HIGHLY MODIFIED PEPTIDE ANTIBIOTIC COMPONENTS OF THIOPEPTIN
}

\author{
Otto D. Hensens* and Georg Albers-Schönberg \\ Department of Analytical Natural Products Chemistry \\ Merck Sharp \& Dohme Research Laboratories, \\ P.O. Box 2000, Rahway, New Jersey 07065, U.S.A.
}

(Received for publication January 20, 1983)

\begin{abstract}
On the basis of ${ }^{1} \mathrm{H}$ and ${ }^{18} \mathrm{C}$ NMR evidence, the structures of two series of the highly modified sulfur-containing peptide antibiotic thiopeptin were elucidated.
\end{abstract}

The thiopeptins produced by Streptomyces tateyamensis belong to a group of highly modified sulfur containing peptide antibiotics ${ }^{1)}$, the structures of several having only recently been determined by X-ray crystallography or physical methods ${ }^{2 \sim 8)}$. They inhibit primarily Gram-positive bacteria ${ }^{\text {g) }}$ and exhibit no significant differences in their inhibition of protein synthesis in cell-free Escherichia coli ${ }^{10)}$. Thiopeptin $\mathrm{B}$, the major component is valuable as a feed-additive because of its marked growth promoting action in swine and chickens ${ }^{11)}$ and was recently shown to be effective as a lactic-acidosis preventive in sheep and cattle ${ }^{12)}$.

Thiopeptin $\mathrm{B}$ and four minor components $\mathrm{A}_{1}, \mathrm{~A}_{2}, \mathrm{~A}_{3}$ and $\mathrm{A}_{4}$ were characterized by MrYAIRI et al..$^{9,13)}$ and shown primarily by acid hydrolysis experiments ${ }^{14)}$ to be closely related to the antibiotic thiostrepton, whose structure, with the exception of the side chain, was determined by X-ray crystallography by ANDERSON and coworkers ${ }^{2)}$. TORI et al., ${ }^{3)}$ from a ${ }^{13} \mathrm{C}$ NMR study of the antibiotic, proposed a sequence consisting of two dehydroalanine (Deala) residues for the side chain which was subsequently confirmed by our own ${ }^{1} \mathrm{H}$ NMR study at $300 \mathrm{MHz}$ (see preceding paper). Of the spectroscopic techniques available to us it soon became apparent that only ${ }^{1} \mathrm{H}$ and ${ }^{13} \mathrm{C}$ NMR spectroscopy were to be potentially useful in the structural elucidation of the thiopeptins. The molecules were not sufficiently volatile to yield a molecular ion even under field-desorption conditions and only a fragment involving the dihydroquinoline moiety and adjacent peptide was identifiable (see below). Moreover, despite the fact that some of the a components were obtained in crystalline form, they were found not to be suitable for X-ray crystallography. A strategy, involving ${ }^{1} \mathrm{H}$ NMR comparison with thiostrepton, was therefore adopted in order to delineate their structural differences. Pertinent details of confirmatory ${ }^{18} \mathrm{C}$ NMR evidence are also discussed ${ }^{15)}$ whereas a full discussion of the ${ }^{13} \mathrm{C}$ NMR assignments is the subject of a companion paper.

\section{Results and Discussion}

Thiopeptin components were separated by silica gel chromatography similar to that previously described $^{9)}$ and found to be homogeneous by TLC. ${ }^{1} \mathrm{H}$ NMR analysis of the components from various batches however, indicated a two compound system in the majority of cases which was confirmed by HPLC. Consistent differences in the ${ }^{1} \mathrm{H}$ NMR spectra allowed them to be grouped into two distinct series arbitrarily designated by the subscripts $\mathbf{a}$ and $\mathbf{b}$ and some of their physical and chemical properties are summarized in Table 1. In some batches all components from the a series and only $\mathrm{A}_{1 \mathrm{~b}}$ from the $\mathbf{b}$ 
Table 1. Physical and chemical data for thiopeptin components.

\begin{tabular}{|c|c|c|c|c|c|}
\hline Component & $\mathrm{Rf}^{\mathrm{a}}$ & $\mathrm{Rf}^{\mathrm{b}}$ & a Series & b Series & $\lambda \frac{\mathrm{MeOH}}{\max }(\mathrm{E} \%) \mathrm{nm}$ \\
\hline Acid & 0.11 & 0.30 & $\mathrm{~B}_{\mathrm{a}}: \mathrm{C}_{71} \mathrm{H}_{84} \mathrm{~N}_{18} \mathrm{O}_{18} \mathrm{~S}_{8}$ & $\mathrm{~B}_{\mathrm{b}}: \mathrm{C}_{71} \mathrm{H}_{82} \mathrm{~N}_{18} \mathrm{O}_{18} \mathrm{~S}_{6}$ & $\mathrm{~B}_{\mathrm{a}}: 250(327)$ \\
\hline Methyl ester & 0.80 & 0.78 & $\mathrm{~A}_{1 \mathrm{a}}: \mathrm{C}_{72} \mathrm{H}_{86} \mathrm{~N}_{18} \mathrm{O}_{10} \mathrm{~S}_{6}$ & $\mathrm{~A}_{1 \mathrm{~b}}: \mathrm{C}_{72} \mathrm{H}_{84} \mathrm{~N}_{18} \mathrm{O}_{18} \mathrm{~S}_{8}$ & $\left\{\begin{array}{l}\mathrm{A}_{1 \mathrm{a}}: 250(331) \\
\mathrm{A}_{1 \mathrm{~b}}: 250(335)\end{array}\right.$ \\
\hline De-Deala (Amide) & 0.54 & 0.52 & $\mathrm{~A}_{4 \mathrm{a}}: \mathrm{C}_{68} \mathrm{H}_{82} \mathrm{~N}_{18} \mathrm{O}_{18} \mathrm{~S}_{6}$ & $\mathrm{~A}_{4 \mathrm{~b}}: \mathrm{C}_{68} \mathrm{H}_{80} \mathrm{~N}_{18} \mathrm{O}_{10} \mathrm{~S}_{6}$ & $\mathrm{~A}_{4 \mathrm{a}}: 250 \mathrm{sh}(281)$ \\
\hline Bis-De-Deala (Amide) & 0.63 & 0.60 & $\mathrm{~A}_{3 \mathrm{a}}: \mathrm{C}_{65} \mathrm{H}_{72} \mathrm{~N}_{17} \mathrm{O}_{15} \mathrm{~S}_{6}$ & $\mathrm{~A}_{3 \mathrm{~b}}: \mathrm{C}_{65} \mathrm{H}_{77} \mathrm{~N}_{17} \mathrm{O}_{15} \mathrm{~S}_{6}$ & $\mathrm{~A}_{3 \mathrm{a}}: 250 \mathrm{sh}(287)$ \\
\hline
\end{tabular}

series were found to be admixed with the corresponding components from the other series. Thiopeptin $\mathbf{B}_{b}$ was separated from $B_{a}$ by multiple preparative TLC on silica gel and thiopeptins $A_{3 b}$ and $A_{4 b}$ were analyzed as mixtures. Insufficient sample in the case of thiopeptin $\mathrm{A}_{2}$ prevented MIYAIRI et al..$^{9)}$ from establishing its uniqueness whereas in our fermentations it was not produced.

\section{${ }^{1} \mathrm{H}$ NMR Spectra-General Features}

Good chemical shift dispersion of all components was obtained under a variety of conditions of solvent and temperature to allow complete analysis of all spin patterns from double resonance experiments. Sharp spectra were obtained for the A components of both series in $\mathrm{CDCl}_{3}$ whereas sharpening of those for $\mathrm{B}_{\mathrm{a}}$ and $\mathrm{B}_{\mathrm{b}}$ could be achieved by the addition of a few drops of DMSO- $d_{6}$ or $\mathrm{CD}_{3} \mathrm{OD}$. As ${ }^{2} \mathrm{H}$-exchange of active hydrogens accompanies the addition of $\mathrm{CD}_{3} \mathrm{OD}$, the data for thiopeptin $\mathrm{B}_{\mathrm{a}}$ in Table 2 were obtained in $\mathrm{CDCl}_{3}$ - DMSO- $d_{6}(16: 1)$ which apparently causes minimal shifts of nonactive hydrogens. Correlations between thiostrepton and thiopeptin spectra were not straightforward due in part to variable positions of the active hydrogens. Also ${ }^{2} \mathrm{H}$-exchange of the $\mathrm{OH}$ signals in the presence of $\mathrm{CD}_{3} \mathrm{OD}$ was initially only of limited use as the addition is accompanied by appreciable solvent shifts of certain resonances as well as slow exchange of peptide $\mathrm{NH}$ protons resulting in concomitant loss of multiplet structure of coupled resonances. Under fully ${ }^{2} \mathrm{H}$-exchanged conditions in $\mathrm{CD}_{3} \mathrm{OD}-\mathrm{CDCl}_{3}(1: 4)$ however, (the components have only limited solubility in $\mathrm{CD}_{3} \mathrm{OD}$ ) requiring at least three days at room temperature, these differences were effectively minimized. An accurate count of peptide $\mathrm{NH}$ protons could thus be made whereas the count for the $\mathrm{OH}$ signals was less reliable even though their temperature dependence and reduction in intensity on irradiation of the water peak as previously demonstrated for thiostrepton, allows them to be readily distinguished from the peptide resonances. After the hydroxyl resonances were identified, correlation of the remainder of proton resonances between thiostrepton and the thiopeptins could be made to within $0.04 \mathrm{ppm}$ but with several exceptions. These were interpreted in terms of four structural changes which will now be discussed.

\section{Nature of Amino Acids}

Amino acid analyses of the acid hydrolysates of the various thiopeptin components (see Table 3 ) gave threonine, valine and alanine in the molar ratio of $1: 1: 2$ as well as the minor products cystine, thiostreptine and 2-aminomethylthiazole-4-carboxylic acid, the latter three products having been observed previously for thiostrepton ${ }^{18)}$. Reduction of thiopeptin $\mathrm{A}_{1 \mathrm{~b}}$ with sodium borohydride prior to hydrolysis increased the value for alanine and showed a peak corresponding to butyrine (see Table 3) suggesting the presence of Deala and dehydrobutyrine residues ${ }^{17}$. That the Ile residue in thiostrepton is replaced by $\mathrm{Val}$ in the thiopeptins and attached to the dihydroquinoline ring was confirmed by mass spectra of the TMS derivatives of all thiopeptins. The highest peak at $\mathrm{m} / \mathrm{z} 521.2687$ 
Table 2. Comparison of ${ }^{1} \mathrm{H}$ NMR assignments of thiostrepton $\mathrm{A}_{1}$ with thiopeptins in $\mathrm{CDCl}_{3}$ at $25^{\circ} \mathrm{C} .{ }^{\mathrm{a}}$

\begin{tabular}{|c|c|c|c|c|c|c|}
\hline \multirow{2}{*}{ Assignment ${ }^{\mathrm{b}}$} & \multicolumn{3}{|c|}{ b Series } & \multicolumn{3}{|c|}{ a Series } \\
\hline & Thiostrepton $\mathrm{A}_{1}$ & Thiopeptin $\mathrm{A}_{1 \mathrm{~b}}$ & Thiopeptin $\mathrm{A}_{1 \mathrm{a}}$ & Thiopeptin $\mathrm{B}_{\mathrm{a}}{ }^{\mathrm{c}}$ & Thiopeptin $\mathrm{A}_{4 \mathrm{a}}$ & Thiopeptin $\mathrm{A}_{3 \mathrm{a}}$ \\
\hline Ile $3-\mathrm{CH}_{3}$ & $0.88 \mathrm{~d}(7)$ & - & - & - & - & - \\
\hline Val $\mathrm{CH}_{3}$ & - & $0.99 \mathrm{~d}(7)$ & $0.98 \mathrm{~d}(7)$ & $0.97 \mathrm{~d}(7)$ & $0.97 \mathrm{~d}(7)$ & $0.97 \mathrm{~d}(7)$ \\
\hline Ile $5-\mathrm{CH}_{3}$ & $0.94 \mathrm{t}(7)$ & - & - & - & - & - \\
\hline Val $\mathrm{CH}_{3}$ & - & $0.99 \mathrm{~d}(7)$ & $0.98 \mathrm{~d}(7)$ & $0.96 \mathrm{~d}(7)$ & $0.97 \mathrm{~d}(7)$ & $0.97 \mathrm{~d}(7)$ \\
\hline Thr $\mathrm{CH}_{3}(1)$ & $0.98 \mathrm{~d}(7)$ & $0.99 \mathrm{~d}(7)$ & $0.98 \mathrm{~d}(7)$ & $0.95 \mathrm{~d}(7)$ & $0.97 \mathrm{~d}(7)$ & $0.97 \mathrm{~d}(7)$ \\
\hline Thr H-3(1) & $1.06 \mathrm{~m}$ & $\sim 1.10 \mathrm{obsc}$ & $\sim 1.15$ obsc & $\sim 1.15 \mathrm{obsc}$ & obse & obsc \\
\hline $\mathrm{Ala} \mathrm{CH}_{3}(1)$ & $1.17 \mathrm{~d}(7)$ & $1.20 \mathrm{~d}(7)$ & $1.22 \mathrm{~d}(7)$ & $1.20 \mathrm{~d}(7)$ & $1.20 \mathrm{~d}(7)$ & $1.19 \mathrm{~d} \mathrm{(7)}$ \\
\hline Thstn $3-\mathrm{CH}_{3}$ & $1.19 \mathrm{~s}$ & $1.21 \mathrm{~s}$ & $1.22 \mathrm{~s}$ & $1.21 \mathrm{~s}$ & $1.21 \mathrm{~s}$ & $1.20 \mathrm{~s}$ \\
\hline $\mathrm{Q} \mathrm{CH}_{3}$ & $1.35 \mathrm{~d}(7)$ & $1.35 \mathrm{~d}(7)$ & $1.35 \mathrm{~d}(7)$ & $1.34 \mathrm{~d}(7)$ & $1.34 \mathrm{~d}(7)$ & $1.35 \mathrm{~d}(7)$ \\
\hline Thstn $5-\mathrm{CH}_{3}$ & $1.36 \mathrm{~d}(7)$ & $1.37 \mathrm{~d}(7)$ & $1.37 \mathrm{~d}(7)$ & $1.36 \mathrm{~d}(7)$ & $1.37 \mathrm{~d}(7)$ & $1.37 \mathrm{~d}(7)$ \\
\hline $\mathrm{Ala} \mathrm{CH}_{3}(2)$ & $1.46 \mathrm{~d}(7)$ & $1.47 \mathrm{~d}(7)$ & $1.55 \mathrm{~d}(7)$ & $1.53 \mathrm{~d}(7)$ & $1.53 \mathrm{~d}(7)$ & $1.51 \mathrm{~d} \mathrm{(7)}$ \\
\hline But $\mathrm{CH}_{3}$ & $1.62 \mathrm{~d}(7)$ & $1.63 \mathrm{~d}(7)$ & $1.64 \mathrm{~d}(7)$ & $1.63 \mathrm{~d}(7)$ & $1.63 \mathrm{~d}(7)$ & $1.63 \mathrm{~d}(7)$ \\
\hline Thr $\mathrm{CH}_{3}(2)$ & $1.75 \mathrm{~d}(7)$ & $1.76 \mathrm{~d}(7)$ & $1.79 \mathrm{~d}(7)$ & $1.78 \mathrm{~d}(7)$ & $1.79 \mathrm{~d}(7)$ & $1.78 \mathrm{~d}(7)$ \\
\hline Ile $\mathrm{H}-3$ & $\sim 1.75$ obsc & - & - & - & - & - \\
\hline Val H-3 & - & $1.88 \mathrm{~h}(\sim 6,7)$ & $1.92 \mathrm{~h}(\sim 6,7)$ & $1.91 \mathrm{~h}(\sim 6,7)$ & $1.90 \mathrm{~h}(\sim 6,7)$ & $1.90 \mathrm{~h}(\sim 6,7)$ \\
\hline Pip $H-4 \beta$ & $2.28 \mathrm{dt}(6,12,12)$ & $2.27 \mathrm{dt}(6,13,13)$ & $2.13 \mathrm{~m}$ & $2.13 \mathrm{~m}$ & $2.11 \mathrm{~m}$ & $2.13 \mathrm{~m}$ \\
\hline Pip H-3 $\alpha$ & $\sim 3.00 \mathrm{obsc}$ & $\sim 3.04$ obsc & $2.13 \mathrm{~m}$ & $2.13 \mathrm{~m}$ & $2.11 \mathrm{~m}$ & $2.13 \mathrm{~m}$ \\
\hline Ile $\mathrm{H}-2$ & $3.01 \mathrm{~d}(6)$ & - & - & - & - & - \\
\hline Val H-2 & - & $2.88 \mathrm{~d}(5.5)$ & $2.88 \mathrm{~d}(6)$ & $2.88 \mathrm{~d}(6)$ & $2.88 \mathrm{~d}(6)$ & $2.88 \mathrm{~d}(6)$ \\
\hline Cys $\mathrm{H}-5 \alpha$ & $3.15 \mathrm{dd}(11.5,13)$ & $3.13 \mathrm{dd}(11.5,13)$ & $3.14 \mathrm{dd}(11,13)$ & $3.16 \mathrm{dd}(11.5,13)$ & $3.12 \mathrm{dd}(12,13)$ & $3.12 \mathrm{dd}(12,13)$ \\
\hline Pip H-3 $\beta$ & $3.50 \mathrm{dd}(6,19)$ & $3.51 \mathrm{dd}(6,19)$ & $2.37 \mathrm{~m}$ & $2.34 \mathrm{~m}$ & $2.35 \mathrm{~m}$ & $2.34 \mathrm{~m}$ \\
\hline Q H-7 $\beta$ & $3.65 \mathrm{dd}(1.5,6)$ & $3.62 \mathrm{dd}(1.5,6)$ & $3.64 \mathrm{dd}(1.5,6)$ & $3.62 \mathrm{dd}(1.5,5.5)$ & $3.62 \mathrm{dd}(1.5,6)$ & $3.63 \mathrm{dd}(1.5,6)$ \\
\hline Cys $\mathrm{H}-5 \beta$ & 3.73 dd $(9,11.5)$ & $3.72 \mathrm{dd}(9,11.5)$ & $3.72 \mathrm{dd}(8.5,11)$ & $3.68 \mathrm{dd}(9,11.5)$ & $3.72 \mathrm{dd}(9,12)$ & $3.72 \mathrm{dd}(9,11)$ \\
\hline Thstn H-4 & $3.84 \mathrm{dq}(5,7)$ & $3.84 \mathrm{dq}(5,7)$ & $3.84 \mathrm{dq}(\sim 5,7)$ & $3.83 \mathrm{dq}(\sim 5,7)$ & $3.83 \mathrm{dq}(\sim 5,7)$ & $3.83 \mathrm{dq}(\sim 5,7)$ \\
\hline Ala H-2(1) & $3.89 \mathrm{dq}(6,7)$ & $3.86 \mathrm{dq}(6,7)$ & $3.88 \mathrm{dq}(6,7)$ & $3.87 \mathrm{dq}(\sim 6,7)$ & $3.88 \mathrm{dq}(6,7)$ & $3.88 \mathrm{dq}(6,7)$ \\
\hline $\mathrm{CO}_{2} \mathrm{CH}_{3}$ & - & $3.93 \mathrm{~s}$ & $3.93 \mathrm{~s}$ & - & - & - \\
\hline Thstn $\mathrm{C} 4-\mathrm{OH}$ & $4.09 \mathrm{~d}(5)$ & $4.06 \mathrm{~d}(5)$ & 4.08 br.s & 4.14 obsc & $4.08 \mathrm{~d}(5)$ & $4.06 \mathrm{~d}(5)$ \\
\hline
\end{tabular}


Table 2. (Continued)

\begin{tabular}{|c|c|c|c|c|c|c|}
\hline \multirow{2}{*}{ Assignment ${ }^{\mathrm{b}}$} & \multicolumn{3}{|c|}{ b Series } & \multicolumn{3}{|c|}{ a Series } \\
\hline & Thiostrepton $\mathrm{A}_{1}$ & Thiopeptin $\mathrm{A}_{1 \mathrm{~b}}$ & Thiopeptin $\mathrm{A}_{1 \mathrm{a}}$ & Thiopeptin $\mathrm{B}_{\mathrm{a}}{ }^{\mathrm{c}}$ & Thiopeptin $\mathrm{A}_{4 a}$ & Thiopeptin $\mathrm{A}_{2 \mathrm{a}}$ \\
\hline Pip H-4 $\alpha$ & $\sim 4.11$ obsc & $4.12 \mathrm{dd}(6,13)$ & 4.16 dd $(3,8)$ & 4.14 dd $(3,8)$ & $4.14 \mathrm{dd}(3,8)$ & $4.18 \mathrm{dd}(2.5,8)$ \\
\hline $\mathrm{OH} / \mathrm{NH}$ & 4.12 br.s & 3.96 br.s & 3.96 br.s & 4.00 br.s & 3.96 br.s & 3.96 br.s \\
\hline Pip $H-2 \beta$ & - & - & $\sim 4.46 \mathrm{obsc}$ & $\sim 4.44 \mathrm{obsc}$ & $\sim 4.46$ obsc & $4.38 \mathrm{dd}(3.5,10)$ \\
\hline Thr H-2(1) & $4.48 \mathrm{dd}(3,8)$ & $4.46 \mathrm{dd}(3,7)$ & $4.46 \mathrm{dd}(3,8)$ & 4.44 dd $(3,8)$ & $4.46 \mathrm{dd}(3,8)$ & 4.46 dd $(3,8)$ \\
\hline Deala $\mathrm{NH}_{2}(3)$ & 4.54 br.s & - & - & - & - & 7.17 br. $\mathrm{s}^{\mathrm{d}}$ \\
\hline Q H-8 $\alpha$ & $4.70 \mathrm{dd}(1.5,8)$ & $4.67 \mathrm{dd}(1.0,8)$ & $4.68 \mathrm{dd}(1.5,8)$ & $4.68 \mathrm{dd}(1.5,8)$ & $4.67 \mathrm{dd}(1.5,8)$ & $4.68 \mathrm{dd}(1.0,8)$ \\
\hline Ala $\mathrm{H}-2(2)$ & $4.79 \mathrm{dq}(7,7)$ & $4.78 \mathrm{dq}(7,7)$ & $4.94 \mathrm{dq}(7,7)$ & $4.93 \mathrm{dq}(7,7)$ & $4.92 \mathrm{dq}(7,7)$ & $4.92 \mathrm{dq}(7,7)$ \\
\hline Cys $\mathrm{H}-4 \beta$ & $4.98 \mathrm{dd}(9,13)$ & $4.96 \mathrm{dd}(9,13)$ & $4.97 \mathrm{dd}(9,13)$ & 4.98 dd $(9,13)$ & $4.97 \mathrm{dd}(9,13)$ & $4.97 \mathrm{dd}(8.5,13)$ \\
\hline Deala $\mathrm{H}-3_{\mathrm{e}}(1)$ & 5.12 br.s & 5.11 br.s & 5.16 br.s & $5.20 \mathrm{br} . \mathrm{s}$ & 5.15 br.s & 5.14 br.s \\
\hline Pip H-6 $\beta$ & 5.23 br.s & 5.26 br.s & $4.47 \mathrm{~s}$ & $4.50 \mathrm{~s}$ & $4.48 \mathrm{~s}$ & $4.48 \mathrm{~s}$ \\
\hline Q H-11 & $\sim 5.34 \mathrm{q} \mathrm{(7)}$ & $5.33 \mathrm{q}(7)$ & $5.35 \mathrm{q} \mathrm{(7)}$ & $5.34 \mathrm{q}(7)$ & $5.35 \mathrm{q} \mathrm{(7)}$ & $5.35 \mathrm{q} \mathrm{(7)}$ \\
\hline $\mathrm{OH} / \mathrm{NH}$ & $5.36 \mathrm{~s}$ & $5.37 \mathrm{~s}$ & $5.40 \mathrm{~s}$ & $5.38 \mathrm{~s}$ & $5.39 \mathrm{~s}$ & $5.38 \mathrm{~s}$ \\
\hline Deala $\mathrm{H}-3_{\mathrm{c}}(3)$ & 5.49 br.s & 5.53 br.s & 5.52 br.s & 5.52 br.s & 5.42 br.s & - \\
\hline Deala $\mathrm{H}-3_{\mathrm{c}}(2)$ & 5.59 br.s & $6.08 \mathrm{~s}$ & $6.05 \mathrm{~s}$ & $6.05 \mathrm{~s}$ & - & - \\
\hline${ }^{\prime} \mathrm{H}_{2} \mathrm{O}$ ' & 5.74 br.s ${ }^{\mathrm{f}}$ & - & - & - & 5.74 br. $\mathrm{s}^{\mathrm{f}}$ & 5.69 br.s \\
\hline Thstn H-2 & $5.79 \mathrm{~d}(10)$ & $5.78 \mathrm{~d}(10)$ & $5.80 \mathrm{~d}(11)$ & $5.83 \mathrm{~d}(10)$ & $5.79 \mathrm{~d}(11)$ & $5.80 \mathrm{~d}(10)$ \\
\hline Deala $\mathrm{H}-3_{t}(1)$ & $5.80 \mathrm{~d}(\sim 2.5)$ & $5.80 \mathrm{~d}(2.5)$ & $5.82 \mathrm{~d}(2.5)$ & $5.82 \mathrm{~d}(2.5)$ & $5.82 \mathrm{~d}(2)$ & $5.82 \mathrm{~d}(2)$ \\
\hline Thr H-2(2) & $5.87 \mathrm{~d}(10)$ & $6.87 \mathrm{~d}(9.5)$ & $6.85 \mathrm{~d}(10)$ & $6.84 \mathrm{~d}(10)$ & $6.85 \mathrm{~d}(10)$ & $6.85 \mathrm{~d}(10)$ \\
\hline But H-3 & $6.22 \mathrm{q}(7)$ & $6.21 \mathrm{q} \mathrm{(7)}$ & $6.23 \mathrm{q} \mathrm{(7)}$ & $6.22 \mathrm{q}(7)$ & $6.22 \mathrm{q}(7)$ & $6.22 \mathrm{q}(7)$ \\
\hline Q H-6 & $6.33 \mathrm{dd}(6,10)$ & $6.34 \mathrm{dd}(6,10)$ & $6.36 \mathrm{dd}(6,10)$ & $6.38 \mathrm{dd}(6,10)$ & $6.35 \mathrm{dd}(6,10)$ & $6.35 \mathrm{dd}(6,10)$ \\
\hline Ala NH(2) & $6.41 \mathrm{~d}(7)$ & $6.35 \mathrm{~d}(7)$ & $6.49 \mathrm{~d}(7)$ & $6.42 \mathrm{~d}(7)$ & $6.45 \mathrm{~d}(7)$ & $6.44 \mathrm{~d}(7)$ \\
\hline Thr H-3(2) & $6.41 \mathrm{q}(7)$ & $6.46 \mathrm{q} \mathrm{(7)}$ & $6.57 q(7)$ & $6.56 \mathrm{q}(7)$ & $6.57 \mathrm{q}(7)$ & $6.55 \mathrm{q}(7)$ \\
\hline Deala $\mathrm{H}-\mathbf{3}_{\mathrm{t}}(3)$ & $6.73 \mathrm{~d}(2.5)$ & $6.75 \mathrm{~s}$ & $6.74 \mathrm{~s}$ & $6.65 \mathrm{~s}$ & - & - \\
\hline Deala $\mathrm{H}-3_{t}(2)$ & $6.83 \mathrm{~d}(2.5)$ & $6.81 \mathrm{~d}(2)$ & $6.80 \mathrm{~d}(\sim 2.5)$ & $6.76 \mathrm{~d}(2)$ & $6.73 \mathrm{~d}(2)$ & - \\
\hline Q C8-OH & $6.86 \mathrm{~d}(8)$ & $6.82 \mathrm{~d}(8)$ & $6.84 \mathrm{~d}(8)$ & $6.65 \mathrm{~d}(8)$ & $6.81 \mathrm{~d}(8)$ & $6.80 \mathrm{~d}(8)$ \\
\hline Q H-5 & $6.92 \mathrm{~d}(10)$ & $6.91 \mathrm{~d}(10.5)$ & $6.94 \mathrm{~d}(10)$ & $6.94 \mathrm{~d}(10)$ & $6.88 \mathrm{~d}(10)$ & $6.87 \mathrm{~d}(10)$ \\
\hline Thr NH(1) & $6.93 \mathrm{~d}(8)$ & $6.96 \mathrm{~d}(7.5)$ & $6.90 \mathrm{~d}(8)$ & $6.90 \mathrm{~d}(8)$ & $6.93 \mathrm{~d}(8)$ & $6.93 \mathrm{~d}(8)$ \\
\hline
\end{tabular}


Table 2. (Continued)

\begin{tabular}{|c|c|c|c|c|c|c|}
\hline \multirow{2}{*}{ Assignment $t^{\mathrm{b}}$} & \multicolumn{3}{|c|}{ b Series } & \multicolumn{3}{|c|}{ a Series } \\
\hline & Thiostrepton $\mathrm{A}_{1}$ & Thiopeptin $\mathrm{A}_{1 \mathrm{~b}}$ & Thiopeptin $\mathrm{A}_{1 \mathrm{a}}$ & Thiopeptin $\mathrm{B}_{\mathrm{a}}{ }^{\mathrm{c}}$ & Thiopeptin $\mathrm{A}_{4 \mathrm{a}}$ & Thiopeptin $\mathrm{A}_{3 \mathrm{a}}$ \\
\hline Q H-3 & $7.34 \mathrm{~s}$ & $7.31 \mathrm{~s}$ & $7.35 \mathrm{~s}$ & $7.33 \mathrm{~s}$ & $7.34 \mathrm{~s}$ & $7.34 \mathrm{~s}$ \\
\hline Thz H-5(3) & $7.49 \mathrm{~s}$ & $7.49 \mathrm{~s}$ & $7.44 \mathrm{~s}$ & $7.44 \mathrm{~s}$ & $7.43 \mathrm{~s}$ & $7.43 \mathrm{~s}$ \\
\hline Thstn $\mathrm{C} 3-\mathrm{OH}$ & $7.54 \mathrm{~s}$ & $7.64 \mathrm{~s}$ & $7.74 \mathrm{~s}$ & $7.60 \mathrm{~s}$ & $7.65 \mathrm{~s}$ & $7.63 \mathrm{~s}$ \\
\hline Ala NH(1) & $7.60 \mathrm{~d}(6)$ & $7.53 \mathrm{~d}(6)$ & $7.59 \mathrm{~d}(6)$ & $7.58 \mathrm{~d}(6)$ & $7.55 \mathrm{~d}(6)$ & $7.55 \mathrm{~d}(6)$ \\
\hline Thstn NH & $7.61 \mathrm{~d}(10)$ & $7.57 \mathrm{~d}(10)$ & $7.60 \mathrm{~d}(10.5)$ & $7.59 \mathrm{~d}(10)$ & $7.58 \mathrm{~d}(10)$ & $7.58 \mathrm{~d}(10)$ \\
\hline Deala NH(1) & 7.84 br.s & 7.82 br.s & 7.87 br.s & 7.90 br.s & 7.86 br.s & 7.86 br.s \\
\hline Thz H-5(1) & $8.15 \mathrm{~s}$ & $8.15 \mathrm{~s}$ & $8.15 \mathrm{~s}$ & $8.15 \mathrm{~s}$ & $8.14 \mathrm{~s}$ & $8.14 \mathrm{~s}$ \\
\hline Thz H-5(4) & $8.30 \mathrm{~s}$ & $8.28 \mathrm{~s}$ & $8.20 \mathrm{~s}$ & $8.18 \mathrm{~s}$ & $8.16 \mathrm{~s}$ & $8.18 \mathrm{~s}$ \\
\hline Thz H-5(2) & $8.31 \mathrm{~s}$ & $8.59 \mathrm{~s}$ & $8.58 \mathrm{~s}$ & $8.57 \mathrm{~s}$ & $8.58 \mathrm{~s}$ & $8.59 \mathrm{~s}$ \\
\hline Thr NH(2) & $8.32 \mathrm{~d}(10)$ & $9.72 \mathrm{~d}(9.5)$ & $9.79 \mathrm{~d}(10)$ & $9.79 \mathrm{~d}(10)$ & $9.75 \mathrm{~d}(\sim 10)$ & $9.77 \mathrm{~d}(10)$ \\
\hline But NH & 8.55 br.s & 8.49 br.s & 8.50 br.s & 8.52 br.s & 8.49 br.s & 8.51 br.s \\
\hline Deala NH(3) & 9.03 br.s & 8.59 br.s & 8.59 br.s & 8.75 br.s & - & - \\
\hline Pip C5-NH & $9.90 \mathrm{~s}$ & $9.92 \mathrm{~s}$ & $9.72 \mathrm{~s}$ & $9.68 \mathrm{~s}$ & $9.73 \mathrm{~s}$ & $9.71 \mathrm{~s}$ \\
\hline Deala NH(2) & 10.00 br.s & 9.99 br.s & 9.93 br.s & 9.96 br.s & 9.93 br.s & - \\
\hline
\end{tabular}

a Chemical shifts in ppm downfield of internal TMS; coupling constants in $\mathrm{Hz}( \pm 0.5)$ are given in brackets.

Abbreviations: $\mathrm{s}=$ singlet, $\mathrm{d}=$ doublet, $\mathrm{dd}=$ doublet of doublets, $\mathrm{t}=$ triplet, $\mathrm{dt}=$ doublet of triplets, $\mathrm{q}=\mathrm{quartet}, \mathrm{dq}=\mathrm{doublet}$ of $\mathrm{quartets}, \mathrm{h}=\mathrm{hextet}, \mathrm{m}=$ multiplet, br $=$ broad, obsc $=$ obscured (overlapping signals).

b See Fig. 1 for subunits.

c In $\mathrm{CDCl}_{3}$ - DMSO- $d_{6}(16: 1)$

d The assignment is for Thz(4) $\mathrm{CONH}_{2}$ in the case of thiopeptin $\mathrm{A}_{3 \mathrm{a}}$.

- Two-proton $\mathrm{H}_{2} \mathrm{O}$ signal.

f Observed at $65^{\circ} \mathrm{C}$. 
Fig. 1. Structure of thiopeptins.
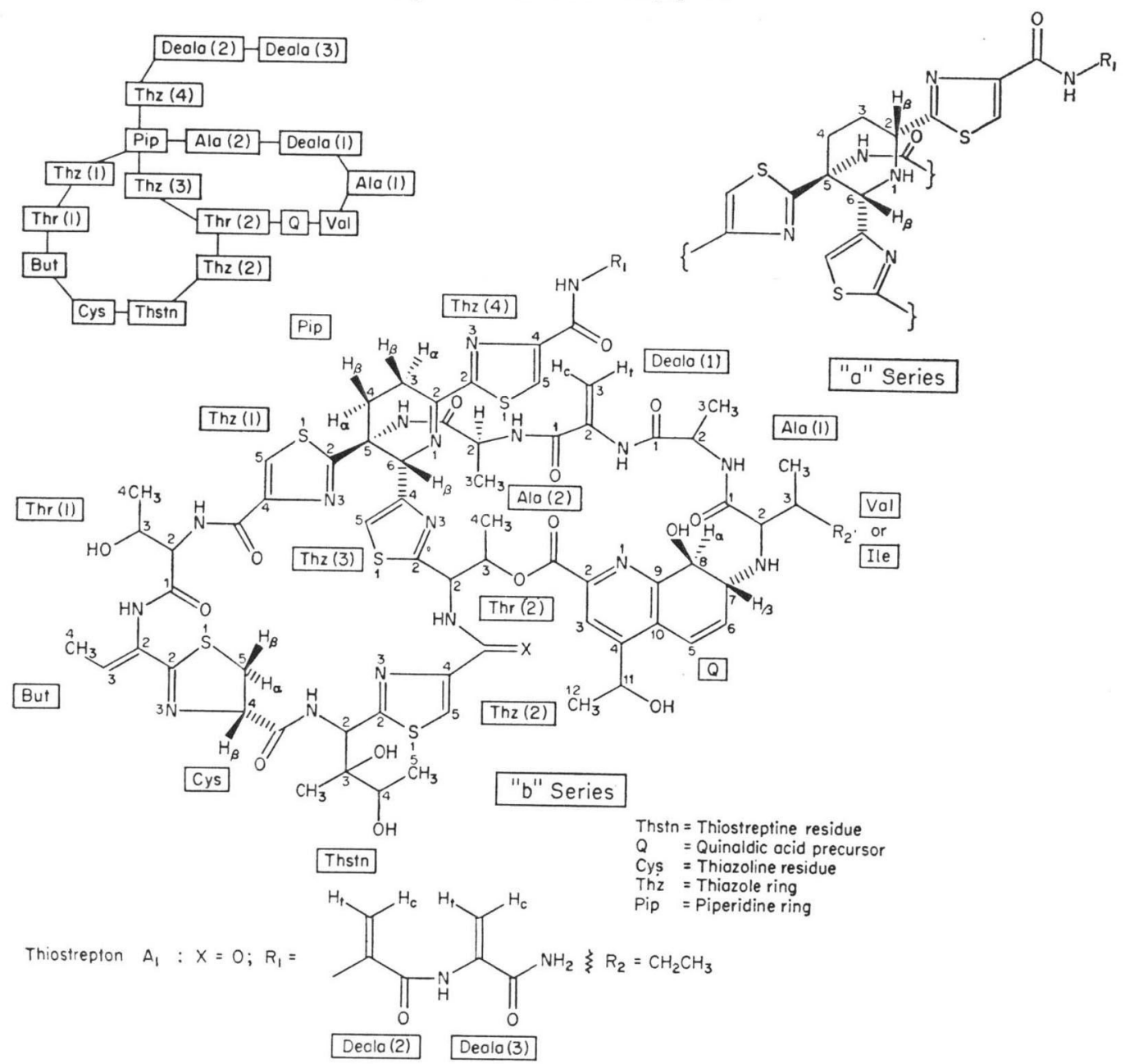

Thiostrepton $A_{2}: X=O ; R_{1}=H$

$\mathrm{R}_{2}=\mathrm{CH}_{2} \mathrm{CH}_{3}$

Thiopeptin $\mathrm{B}_{0} / \mathrm{B}_{\mathrm{b}}: \mathrm{X}=\mathrm{S} ; \mathrm{R}_{1}=$

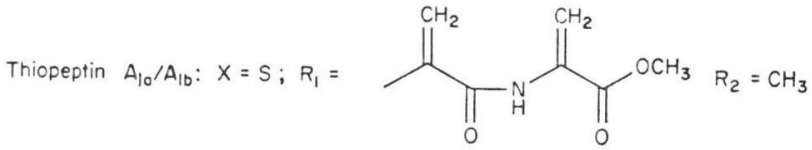

Thiopeptin $A_{4 a} / A_{40}: X=S ; R_{1}=\prod_{0} R_{2} H_{2}$

Thiopeptin $A_{3 a} / A_{3 b}: X=S \quad R_{1}=H \quad R_{2}=C_{3}$ 
Table 3. Amino acid analysis of acid hydrolysates of thiopeptins. ${ }^{\text {a }}$

\begin{tabular}{lccrrrrr}
\hline \multicolumn{1}{c}{ Amino acid } & $\mathrm{A}_{1 \mathrm{~b}}$ & $\mathrm{~A}_{1 \mathrm{~b}}{ }^{\mathrm{c}}$ & $\mathrm{A}_{1 \mathrm{a}}$ & \multicolumn{1}{c}{$\mathrm{B}_{\mathrm{a}}$} & $\mathrm{A}_{4 \mathrm{a}}$ & $\mathrm{A}_{3 \mathrm{a}}$ \\
\hline Threonine & 0.58 & 0.52 & 0.52 & 0.57 & 0.53 & 0.56 \\
Alanine & 0.99 & 1.30 & 0.95 & 0.98 & 0.96 & 0.91 \\
Valine & 0.50 & 0.43 & 0.52 & 0.53 & 0.51 & 0.55 \\
Cystine & 0.25 & 0.30 & Small & Small & Small & Small \\
Thiostreptine & 0.11 & 0.11 & 0.12 & 0.13 & 0.11 & 0.14 \\
ATC & 0.13 & 0.13 & 0.08 & 0.09 & 0.08 & 0.09 \\
Butyrine & - & 0.08 & - & - & - & - \\
\hline
\end{tabular}

a Values in $\mu \mathrm{mol} / \mathrm{mg}$ of thiopeptin.

b 2-Aminomethylthiazole-4-carboxylic acid.

c Reduced with $\mathrm{NaBH}_{4}$ prior to hydrolysis.

which corresponds to fragment a (calcd. 521.2686)

(Fig. 2) can readily aromatize with loss of TM$\mathrm{SOH}$ to fragment $\mathbf{b}(\mathrm{m} / \mathrm{z}$ 431.2187, calcd. 431.2185), whereas the corresponding peaks in thiostrepton occur at 14 mass units higher. Subsequent measurements on the deuterated silyl derivatives confirmed the presence of two and three silyl groups in the fragments $\mathbf{b}$ and a respectively.

Examination of the methyl region of the ${ }^{1} \mathrm{H}$ NMR spectrum of thiostrepton reveals eight doublets, one triplet and a singlet whereas spectra of the thiopeptins have one extra doublet replacing the triplet. This doublet which occurs at $\delta 0.98$ in $\mathrm{A}_{1 \mathrm{a}}$ in $\mathrm{CDCl}_{\hat{s}}$ (see Table 4) was shown to be coupled to a resonance at $\delta 1.92(\mathrm{Val} \mathrm{H}-3)$ which appears as a hextet (two overlapping heptets with outer satellites not observed) which in turn is coupled to a second methyl group at $\delta 0.98$ and a doublet at 2.88 (Val H-2). Irradiation of this doublet collapses the hextet to a quintet thus confirming the presence of a Val residue. No coupling between Val H-2 and the adjacent amine NH proton as in thiostrepton was noted presumably due to an unfavorable rate of exchange between bulk water and the NH proton. Analogously, the threonine and two alanine resonances were identified but in these cases coupling of the amide $\mathrm{NH}$ to the adjacent methine proton readily supports their identification. The chemical shift of the highly shielded resonance for Thr H-3(1) has been discussed for thiostrepton (see companion paper) and reflects a similar proximity of the proton to the ring currents of the dihydroquinoline ring. This resonance is not obscured in thiopeptin $\mathrm{A}_{1 \mathrm{~b}}$ in $\mathrm{CDCl}_{3}$ and irradiation at this position ( $\left.\delta 1.10\right)$ causes one of the three methyl doublets at $\delta 0.99$ to collapse to a singlet and the doublet of doublets at $\delta 4.46$ to a doublet $\left(J_{\mathrm{H} 2, \mathrm{H} 3}=\right.$ $3 \mathrm{~Hz}$ ). Irradiation of the latter resulted in collapse of the doublet at $\delta 6.96$ to a singlet and the resonance at $\delta 1.10$ to a quartet thereby confirming the presence of the Thr (1) residue.

Nature of Thiazoline (Cys), Dihydroquinoline (Q) and Esterified Threonine (Thr (2)) Rings

It is evident from Table 5 that the thiazoline (Cys) and dihydroquinoline (Q) ring systems of thiostrepton are retained in both series of thiopeptins. Besides chemical shift, the various coupling constants in both series were found to be identical to that in thiostrepton implying similar conformations of the envelope and flattened half-chair forms of the thiazoline and dihydroquinoline rings respectively.

Assignment of the protons of the modified threonine residue attached to $\mathrm{C} 6$ of the piperidine ring 
Table 4. Comparison of ${ }^{1} \mathrm{H}$ NMR assignments of amino acid residues in thiostrepton $\mathrm{A}_{1}$ and thiopeptins $\mathrm{A}_{1 \mathrm{a}}$ and $\mathrm{A}_{1 \mathrm{~b}}$ in $\mathrm{CDCl}_{3}$ and $\mathrm{CD} \mathrm{OD}_{3}-\mathrm{CDCl}_{3}$ $(1: 4)$ at $25^{\circ} \mathrm{C}^{\mathrm{a}}$

\begin{tabular}{|c|c|c|c|c|c|c|}
\hline \multirow{2}{*}{ Assignment } & \multicolumn{2}{|c|}{ Thiostrepton $\mathrm{A}_{1}$} & \multicolumn{2}{|c|}{ Thiopeptin $\mathrm{A}_{1 \mathrm{~b}}$} & \multicolumn{2}{|c|}{ Thiopeptin $\mathrm{A}_{1 \mathrm{a}}$} \\
\hline & $\mathrm{CDCl}_{3}$ & $\mathrm{CD}_{3} \mathrm{OD}-\mathrm{CDCl}_{3}(1: 4)$ & $\mathrm{CDCl}_{3}$ & $\mathrm{CD}_{3} \mathrm{OD}-\mathrm{CDCl}_{3}(1: 4)$ & $\mathrm{CDCl}_{3}$ & $\mathrm{CD}_{3} \mathrm{OD}-\mathrm{CDCl}_{3}(1: 4)$ \\
\hline \multicolumn{7}{|l|}{ Ile } \\
\hline H-2 & $3.01 \mathrm{~d}(6)$ & $3.02 \mathrm{~d}(4)$ & - & - & - & - \\
\hline $\mathrm{H}-3$ & $\sim 1.75$ obsc & $1.98 \mathrm{~m}$ & - & - & - & - \\
\hline $3-\mathrm{CH}_{3}$ & $0.88 \mathrm{~d}(7)$ & $0.82 \mathrm{~d}(7)$ & - & - & - & - \\
\hline $4-\mathrm{CH}_{2}$ & $\sim 1.20$ obsc & obsc & - & - & - & - \\
\hline $5-\mathrm{CH}_{2}$ & 0.94 t (7) & $0.90 \mathrm{t}(7)$ & - & - & - & - \\
\hline \multicolumn{7}{|l|}{ Val } \\
\hline H-2 & - & - & $2.88 \mathrm{~d}(5.5)$ & $2.97 \mathrm{~d}(4)$ & $2.88 \mathrm{~d}(6)$ & $2.94 \mathrm{~d}(4)$ \\
\hline H-3 & - & - & $1.88 \mathrm{~h}(\sim 6,7)$ & $\sim 2.33 \mathrm{~m}$ & $1.92 \mathrm{~h}(\sim 6,7)$ & $2.23 \mathrm{~m}$ \\
\hline $4-\mathrm{CH}_{3}$ & - & - & $0.99 \mathrm{~d}(7)$ & $0.78 \mathrm{~d}(7)$ & $0.98 \mathrm{~d}(7)$ & $0.82 \mathrm{~d}(7)$ \\
\hline 4- $\mathrm{CH}_{3}$ & - & - & $0.99 \mathrm{~d}(7)$ & $0.79 \mathrm{~d}(7)$ & $0.98 \mathrm{~d}(7)$ & $0.82 \mathrm{~d}(7)$ \\
\hline \multicolumn{7}{|l|}{$\operatorname{Thr}(1)$} \\
\hline $\mathrm{NH}$ & $6.93 \mathrm{~d}(8)$ & $7.16(8) \rightarrow 0$ & $6.96 \mathrm{~d}(7.5)$ & - & $6.90 \mathrm{~d}(8)$ & - \\
\hline $\mathrm{H}-2$ & 4.48 dd $(3,8)$ & $4.48 \mathrm{dd} \rightarrow \mathrm{d}(3)$ & 4.46 dd $(3,7)$ & $4.45 \mathrm{dd} \rightarrow \mathrm{d}(3.5)$ & 4.46 dd $(3,8)$ & 4.42 obsc \\
\hline $\mathrm{H}-3$ & $1.06 \mathrm{~m}$ & $\sim 1.63 \mathrm{obsc}$ & $\sim 1.10 \mathrm{~m}$ & obsc & $\sim 1.15$ obsc & obsc \\
\hline 4- $\mathrm{CH}_{3}$ & $0.98 \mathrm{~d}(7)$ & $1.04 \mathrm{~d}(7)$ & $0.99 \mathrm{~d}(7)$ & $1.09 \mathrm{~d}(7)$ & $0.98 \mathrm{~d}(7)$ & $1.06 \mathrm{~d}(7)$ \\
\hline \multicolumn{7}{|l|}{$\operatorname{Ala}(1)$} \\
\hline $\mathrm{NH}$ & $7.60 \mathrm{~d}(6)$ & $7.86 \mathrm{~d}(6) \rightarrow 0$ & $7.53 \mathrm{~d}(6)$ & - & $7.59 \mathrm{~d}(6)$ & - \\
\hline $\mathrm{H}-2$ & $3.89 \mathrm{dq}(6,7)$ & $3.85 \mathrm{dq} \rightarrow \mathrm{q}(7)$ & $3.86 \mathrm{dq}(6,7)$ & $3.84 \mathrm{dq} \rightarrow \mathrm{q}(7)$ & $3.88 \mathrm{dq}(6,7)$ & $3.84 \mathrm{dq} \rightarrow \mathrm{q}(7)$ \\
\hline 3- $\mathrm{CH}_{3}$ & $1.17 \mathrm{~d}(7)$ & $1.20 \mathrm{~d}(7)$ & $1.20 \mathrm{~d} \mathrm{(7)}$ & $1.18 \mathrm{~d}(7)$ & $1.22 \mathrm{~d}(7)$ & $1.20 \mathrm{~d}(7)$ \\
\hline \multicolumn{7}{|l|}{$\mathrm{Ala}(2)$} \\
\hline $\mathrm{NH}$ & $6.41 \mathrm{~d}(7)$ & $7.16 \mathrm{~d}(7) \rightarrow o$ & $6.35 \mathrm{~d}(7)$ & - & $6.49 \mathrm{~d}(7)$ & $7.12 \mathrm{~d} \rightarrow \mathrm{o}$ \\
\hline $\mathrm{H}-2$ & $4.79 \mathrm{dq}(7,7)$ & $4.78 \mathrm{dq} \rightarrow \mathrm{q}(7)$ & $4.78 \mathrm{dq}(7,7)$ & $4.78 \mathrm{dq} \rightarrow \mathrm{q}(7)$ & $4.94 \mathrm{dq}(7,7)$ & $4.92 \mathrm{dq} \rightarrow \mathrm{q}(7)$ \\
\hline $3-\mathrm{CH}_{3}$ & $1.46 \mathrm{~d}(7)$ & $1.47 \mathrm{~d}(7)$ & $1.47 \mathrm{~d}(7)$ & $1.47 \mathrm{~d}(7)$ & $1.55 \mathrm{~d}(7)$ & $1.52 \mathrm{~d}(7)$ \\
\hline
\end{tabular}

a Multiplicity changes on ${ }^{2} \mathrm{H}$-exchange are indicated by $\rightarrow$; complete disappearance of an active hydrogen is designated by $\mathrm{s} \rightarrow \mathrm{o}$ or $\mathrm{d} \rightarrow \mathrm{o}$. 
Table 5. Comparison of ${ }^{1} \mathrm{H}$ NMR assignments of thiazoline (Cys) and dihydroquinoline (Q) rings in thiostrepton $\mathrm{A}_{1}$ and thiopeptins $\mathrm{A}_{1 \mathrm{a}}$ and $\mathrm{A}_{1 \mathrm{~b}}$ in $\mathrm{CDCl}_{3}$ and $\mathrm{CD}_{3} \mathrm{OD}-\mathrm{CDCl}_{3}(1: 4)$ at $25^{\circ} \mathrm{C}$.

\begin{tabular}{|c|c|c|c|c|c|c|c|}
\hline & \multirow{2}{*}{ Assignment } & \multicolumn{2}{|c|}{ Thiostrepton $\mathrm{A}_{1}$} & \multicolumn{2}{|c|}{ Thiopeptin $\mathrm{A}_{1 \mathrm{~b}}$} & \multicolumn{2}{|c|}{ Thiopeptin $\mathrm{A}_{1 \mathrm{a}}$} \\
\hline & & $\mathrm{CDCl}_{3}$ & $\mathrm{CD}_{3} \mathrm{OD}-\mathrm{CDCl}_{3}(1: 4)$ & $\mathrm{CDCl}_{3}$ & $\mathrm{CD}_{3} \mathrm{OD}-\mathrm{CDCl}_{3}(1: 4)$ & $\mathrm{CDCl}_{3}$ & $\mathrm{CD}_{3} \mathrm{OD}-\mathrm{CDCl}_{3}(1: 4)$ \\
\hline \multirow[t]{3}{*}{ Cys } & $\mathrm{H}-4 \beta$ & $4.98 \mathrm{dd}(9,13)$ & $5.02 \mathrm{dd}(9,13)$ & $4.96 \mathrm{dd}(9,13)$ & $5.01 \mathrm{dd}(9,13)$ & $4.97 \mathrm{dd}(9,13)$ & $5.00 \mathrm{dd}(9,13)$ \\
\hline & $\mathrm{H}-5 \beta$ & $3.73 \mathrm{dd}(9,11.5)$ & $3.69 \mathrm{dd}(9,11)$ & $3.72 \mathrm{dd}(9,11.5)$ & $3.69 \mathrm{dd}(9,11)$ & $3.72 \mathrm{dd}(8.5,11)$ & 3.68 dd $(9,11)$ \\
\hline & $\mathrm{H}-5 \alpha$ & $3.15 \mathrm{dd}(11.5,13)$ & $3.21 \mathrm{dd}(11,13)$ & $3.13 \mathrm{dd}(11.5,13)$ & $3.21 \mathrm{dd}(11,13)$ & $3.14 \mathrm{dd}(11,13)$ & $3.17 \mathrm{dd}(11,13)$ \\
\hline \multirow[t]{7}{*}{ Q } & $\mathrm{H}-5$ & $6.92 \mathrm{~d}(10)$ & $6.95 \mathrm{~d}(10)$ & $6.91 \mathrm{~d}(10.5)$ & $6.96 \mathrm{~d}(10)$ & $6.94 \mathrm{~d}(10)$ & $6.96 \mathrm{~d}(10)$ \\
\hline & H-6 & $6.33 \mathrm{dd}(6,10)$ & $6.46 \mathrm{dd}(6,10)$ & $6.34 \mathrm{dd}(6,10)$ & $6.46 \mathrm{dd}$, obsc & $6.36 \mathrm{dd}(6,10)$ & $6.47 \mathrm{dd}(6,10)$ \\
\hline & $\mathrm{H}-7$ & $3.65 \mathrm{dd}(1.5,6)$ & $3.67 \mathrm{dd}(1.5,6)$ & $3.62 \mathrm{dd}(1.5,6)$ & $3.64 \mathrm{dd}(1.5,6)$ & $3.64 \mathrm{dd}(1.5,6)$ & $3.62 \mathrm{dd}(2,6)$ \\
\hline & $\mathrm{H}-8$ & $4.70 \mathrm{dd}(1.5,8)$ & $4.43 \mathrm{dd} \rightarrow \mathrm{d}(1.5)$ & $4.67 \mathrm{dd}(1.0,8)$ & $4.39 \mathrm{dd} \rightarrow$ br.s & $4.68 \mathrm{dd}(1.5,8)$ & $4.44 \mathrm{dd} \rightarrow$ br.s \\
\hline & $\mathrm{C} 8-\mathrm{OH}$ & $6.86 \mathrm{~d}(8)$ & - & $6.82 \mathrm{~d}(8)$ & - & $6.84 \mathrm{~d}(8)$ & - \\
\hline & $\mathrm{H}-11$ & $\sim 5.34 \mathrm{q}(7)$ & $\sim 5.36$ obsc & $5.33 \mathrm{q}(7)$ & $\sim 5.37 \mathrm{q}$, obsc. & $5.35 \mathrm{q} \mathrm{(7)}$ & $5.37 \mathrm{q}(7)$ \\
\hline & $12-\mathrm{CH}_{3}$ & $1.35 \mathrm{~d}(7)$ & $1.42 \mathrm{~d}(7)$ & $1.35 \mathrm{~d}(7)$ & $1.42 \mathrm{~d}(7)$ & $1.35 \mathrm{~d}(7)$ & $1.40 \mathrm{~d}(7)$ \\
\hline
\end{tabular}


Table 6. ${ }^{1} \mathrm{H}$ NMR assignments of thiostreptine (Thstn) and threonine residues (Thr (2)) in thiostrepton $\mathrm{A}_{1}$ and thiopeptins $\mathrm{A}_{1 \mathrm{a}}$ and $\mathrm{A}_{1 \mathrm{~b}}$ in $\mathrm{CDCl}_{3}$ and $\mathrm{CD}_{3} \mathrm{OD}-\mathrm{CDCl}_{3}(1: 4)$ at $25^{\circ} \mathrm{C}$.

\begin{tabular}{|c|c|c|c|c|c|c|}
\hline \multirow{2}{*}{ Assignment } & \multicolumn{2}{|c|}{ Thiostrepton $\mathrm{A}_{1}$} & \multicolumn{2}{|c|}{ Thiopeptin $\mathrm{A}_{1 \mathrm{~b}}$} & \multicolumn{2}{|c|}{ Thiopeptin $\mathbf{A}_{1 \mathrm{a}}$} \\
\hline & $\mathrm{CDCl}_{3}$ & $\begin{array}{c}\mathrm{CD}_{3} \mathrm{OD}- \\
\mathrm{CDCl}_{3}(1: 4)\end{array}$ & $\mathrm{CDCl}_{3}$ & $\begin{array}{c}\mathrm{CD}_{3} \mathrm{OD}- \\
\mathrm{CDCl}_{3}(1: 4)\end{array}$ & $\mathrm{CDCl}_{3}$ & $\begin{array}{c}\mathrm{CD}_{3} \mathrm{OD}- \\
\mathrm{CDCl}_{3}(1: 4)\end{array}$ \\
\hline Thr Me (2) & $1.75 \mathrm{~d}(7)$ & $1.76 \mathrm{~d}(7)$ & $1.76 \mathrm{~d}(7)$ & $1.74 \mathrm{~d}(7)$ & $1.79 \mathrm{~d}(7)$ & $1.76 \mathrm{~d}(7)$ \\
\hline Thr H-3 (2) & $6.41 \mathrm{q}(7)$ & $6.41 \mathrm{q} \mathrm{(7)}$ & $6.46 \mathrm{q}(7)$ & $6.45 \mathrm{q}(7)$ & $6.57 \mathrm{q}(7)$ & $6.47 \mathrm{q}(7)$ \\
\hline Thr H-2 (2) & $5.87 \mathrm{~d}(10)$ & 5.84 br.s & $6.87 \mathrm{~d}(9.5)$ & 6.86 br.s & $6.85 \mathrm{~d}(10)$ & 6.82 br.s \\
\hline Thr NH (2) & $8.32 \mathrm{~d}(10)$ & - & $9.72 \mathrm{~d}(9.5)$ & - & $9.79 \mathrm{~d}(10)$ & - \\
\hline Thstn $\mathrm{H}-2$ & $5.79 \mathrm{~d}(10)$ & $5.80 \mathrm{~s}$ & $5.78 \mathrm{~d}(10)$ & $5.78 \mathrm{~s}$ & $5.80 \mathrm{~d}(11)$ & $5.78 \mathrm{~s}$ \\
\hline Thstn NH & $7.61 \mathrm{~d}(10)$ & - & $7.57 \mathrm{~d}(10)$ & - & $7.60 \mathrm{~d}(10.5)$ & - \\
\hline
\end{tabular}

through Thz (3) in thiostrepton and thiopeptins was complicated by the almost zero coupling between $\mathrm{H}$ 2 and $\mathrm{H}-3$, making the $\mathrm{CHNH}$ proton doublets difficult to distinguish from the pair for the thiostreptine (Thstn) residue (see Table 6). In the case of thiostrepton $\mathrm{A}_{1}$ (see companion paper) this problem was solved by double resonance experiments in $\mathrm{CD}_{3} \mathrm{OD}-\mathrm{CDCl}_{3}(1: 4)$ where, even though not resolved, the broader singlet at $\delta 5.84$ was shown to be coupled to the quartet at $\delta 6.41$ which in turn was coupled to the most downfield methyl doublet at $\delta 1.76$, thus defining the $\mathrm{CH}_{3} \mathrm{CHCH}$ sequence in Thr (2). Whereas Thstn $\mathrm{H}-2$ and Thr H-2 (2) have similar chemical shifts in thiostrepton $\mathrm{A}_{1}$, one of the doublets as well as the corresponding $\mathrm{NH}$ doublet, occur significantly to lower field in both series of the thiopeptins. That the downfield shifted resonances are in fact due to the $\mathrm{CHNH}$ protons of $\mathrm{Thr}$ (2) was similarly confirmed for $\mathrm{A}_{1 \mathrm{a}}$ in $\mathrm{CD}_{3} \mathrm{OD}-\mathrm{CDCl}_{3}(1: 4)$ at $25^{\circ} \mathrm{C}$, but unequivocally at $65^{\circ} \mathrm{C}$ where now the small coupling of $\mathrm{ca} 1.0 \mathrm{~Hz}$ between $\mathrm{H}-2$ and $\mathrm{H}-3$ resolved giving a doublet of quartets $(J=1.0,7.0 \mathrm{~Hz})$ for $\mathrm{H}-3$.

The reason for the appreciable downfield shifts of the $\mathrm{CHNH}$ protons in Thr (2) became clear from a ${ }^{13} \mathrm{C}$ NMR analysis of the thiopeptins and thiostrepton $\mathrm{A}_{1}$. In both series of thiopeptins a peak appears at $189.9 \mathrm{ppm}$ in $\mathrm{CD}_{3} \mathrm{OH}-\mathrm{CDCl}_{3}(1: 4)$, downfield of all other resonances and giving a broadened singlet on gated decoupling. When measured in the fully deuterated solvent mixture a split peak is observed suggesting a carbonyl group flanked by a slowly exchanging peptide $\mathrm{NH}$ group ${ }^{18)}$. Earlier microanalytical data on the thiopeptins ${ }^{9)}$ as well as our own, indicate a higher sulfur content compared to thiostrepton and taken together with the unusual low field position of the amide carbon, a thiocarbonyl group was entertained which readily accounts for the yellow color of all thiopeptins. Thiocarbonyl groups have been shown by KaLINOwSKI and KESSLER ${ }^{19)}$ to appear downfield of their oxygen analogues in a predictable manner by the relationship $\delta_{\mathrm{C}=\mathrm{s}}=1.45 \delta_{\mathrm{C}=0}-46.5 \mathrm{ppm}$; this relationship also holds true for various aromatic amides (see companion paper). On calculation, this gives $\delta_{\mathrm{C}=0}=163.0 \mathrm{ppm}$ for $\delta_{\mathrm{C}=\mathrm{S}}=189.9 \mathrm{ppm}$ in very good agreement with that assigned to the corresponding amide carbonyl in thiostrepton (161.1 ppm) and that observed in the model compound thiazole-4-carboxamide in DMSO- $d_{6}$ $(162.8 \mathrm{ppm})$. The thiocarbonyl resonance $189.7 \mathrm{ppm}$ in the thio-analogue of the thiazole-4-carboxamide moreover supports the proposed modification. The downfield shifts of the CHNH proton doublets can now be readily understood in terms of the diamagnetic anisotropy of the thioamide group ${ }^{20)}$. In particular the shifts observed for the methine proton of the model amide $N$-methyl- $N$-isopropyl acetamide compared to the corresponding thio-analogue are 1.10 and $0.47 \mathrm{ppm}$ for the $Z$ and $E$ isomers respectively ${ }^{21}$ ) thus favoring the $Z$ configuration as found in thiostrepton.

\section{Nature of Piperidine (Pip) Ring}

The only difference that distinguishes the two series of thiopeptins, originates in the piperidine ring 
which will be discussed separately for each series.

\section{b Series}

Table 7 summarizes the ${ }^{1} \mathrm{H}$ NMR data of the piperidine ring protons of thiostrepton $\mathrm{A}_{1}$ and thiopeptin $\mathrm{A}_{1 \mathrm{~b}}$ at two different temperatures in $\mathrm{CDCl}_{3}$. The doublet of doublets for Pip $\mathrm{H}-4 \alpha$, obscured by the residual water peak at $25^{\circ} \mathrm{C}$ is clearly visible at higher temperatures. It is abundantly clear from the Table that both compounds have the same $\Delta^{1}$-piperidine ring system. As was pointed out previously from a first order analysis of the four spin $\mathrm{CH}_{2} \mathrm{CH}_{2}$ system in thiostrepton, the chemical shifts are anomalous and are attributed to the neighboring ring currents of the thiazole substituents at Pip $\mathrm{C} 2, \mathrm{C} 5$ and C6. The chemical shifts therefore depend critically on the overall conformation of this moiety and provides strong evidence not only for the same relative, but also absolute configuration of the thiazole rings at these centers. In addition to the geminal and vicinal coupling constants which characterize the first order spin pattern in thiopeptin $\mathrm{A}_{1 \mathrm{~b}}$, the homoallylic couplings of 1.5 and $3.5 \mathrm{~Hz}$ involving $\mathrm{H}-6 \beta$ with $\mathrm{H}-3$ and $\mathrm{H}-3 \alpha$ respectively, were confirmed. These couplings were removed by addition of trifluoroacetic acid- $d$ (TFA- $d$ ) because of ${ }^{2} \mathrm{H}$-exchange of the allylic hydrogens at $\mathrm{C} 3$ via an imine-enamine equilibrium as observed in the case of thiostrepton.

\section{a Series}

The first order four spin $\mathrm{CH}_{2} \mathrm{CH}_{2}$ pattern in the $\mathbf{b}$ series is replaced by a more complex second order five spin system for members of the a series. The spin system defied analysis in $\mathrm{CDCl}_{3}$ or $\mathrm{CD}_{3} \mathrm{OD}$ $\mathrm{CDCl}_{3}(1: 4)$ because of poor resolution of the two upfield multiplets. Upon addition of TFA- $d$ to $\mathrm{B}_{\mathrm{a}}$, $\mathrm{A}_{1 \mathrm{a}}$ or $\mathrm{A}_{3 \mathrm{a}}$ in $\mathrm{CD}_{3} \mathrm{OD}-\mathrm{CDCl}_{3}(1: 9)$ however, all five resonances move to lower field including the singlet $\mathrm{H}_{\mathrm{F}}$ at $\delta 4.53$ in $\mathrm{A}_{1 \mathrm{a}}$ (see Table 8), reminiscent of the protonation of an amine. For all three components, the protonation shifts for $H_{E}$ and $H_{F}$ were always observed to be the same and the largest which suggested an amine function flanked by two methine groups. The results therefore suggested the

Table 7. Comparison of ${ }^{1} \mathrm{H}$ NMR assignments of $\Delta^{1}$-piperidine ring in thiostrepton $\mathrm{A}_{1}$ with thiopeptin $\mathrm{A}_{1 \mathrm{~b}}$ in $\mathrm{CDCl}_{3}$ at $25^{\circ} \mathrm{C}$ and $45^{\circ} \mathrm{C}$.

\begin{tabular}{|c|c|c|c|c|}
\hline \multirow{2}{*}{ Assignment } & \multicolumn{2}{|c|}{ Thiostrepton $\mathrm{A}_{1}$} & \multicolumn{2}{|c|}{ Thiopeptin $\mathrm{A}_{1 \mathrm{~b}}$} \\
\hline & $25^{\circ} \mathrm{C}$ & $45^{\circ} \mathrm{C}$ & $25^{\circ} \mathrm{C}$ & $45^{\circ} \mathrm{C}$ \\
\hline Pip $\mathrm{H}-3 \beta$ & $3.50 \mathrm{dd}(6,19)$ & $3.50 \mathrm{dd}(6,19)$ & $3.51 \mathrm{dd}(6,19)$ & $3.50 \mathrm{dd}(6,19)$ \\
\hline Pip H-3 $\alpha$ & $\sim 3.00$ obsc & $\sim 3.00 \mathrm{~m}$ & $\sim 3.04$ obsc. & $\sim 3.03 \mathrm{~m}$ \\
\hline Pip $H-4 \beta$ & $2.28 \mathrm{dt}(6,12,12)$ & $2.29 \mathrm{dt}(6,12,12)$ & $2.27 \mathrm{dt}(6,12.5,12.5)$ & $2.27 \mathrm{dt}(6,12.5,12.5)$ \\
\hline Pip H- $4 \alpha$ & $\sim 4.11$ obsc. & $4.14 \mathrm{dd}(6,12)$ & $4.12 \mathrm{dd}(6,12.5)$ & $4.14 \mathrm{dd}(6,12.5)$ \\
\hline 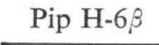 & 5.23 br.s & 5.24 br.s. & 5.26 br.s. & 5.27 br.s. \\
\hline
\end{tabular}

Table 8. ${ }^{1} \mathrm{H}$ NMR assignments and protonation shifts of piperidine ring protons in thiopeptin $\mathrm{A}_{1 a}$ with TFA- $d$ in $\mathrm{CD}_{3} \mathrm{OD}-\mathrm{CDCl}_{3}(1: 9)$ at $45^{\circ} \mathrm{C}$.

\begin{tabular}{|c|c|c|c|c|}
\hline \multirow{2}{*}{ Symbol $^{\mathrm{a}}$} & \multirow{2}{*}{ Assignment } & \multicolumn{2}{|c|}{$\mathrm{CD}_{3} \mathrm{OD}-\mathrm{CDCl}_{3}(1: 9)$} & \multirow{2}{*}{$\Delta \delta(\mathrm{ppm})$} \\
\hline & & No TFA-d & $+10 \%$ TFA- $d$ & \\
\hline A & Pip $H-4 \beta$ & $2.13 \mathrm{~m}$ & $2.37 \mathrm{dt}(3.5,13,13)$ & 0.24 \\
\hline B & Pip $\mathrm{H}-3 \alpha$ & $2.13 \mathrm{~m}$ & $\sim 2.56 \mathrm{~m}$ & 0.43 \\
\hline $\mathrm{C}$ & Pip $H-3 \beta$ & $2.37 \mathrm{~m}$ & $\sim 2.49 \mathrm{~m}$ & 0.12 \\
\hline D & Pip $\mathrm{H}-4 \alpha$ & 4.16 br.dd $(\sim 4,10)$ & 4.32 br.d (12.5) & 0.16 \\
\hline $\mathrm{E}$ & Pip $\mathrm{H}-2 \beta$ & $4.43 \mathrm{dd}(3.5,10)$ & $5.07 \mathrm{dd}(4,10)$ & 0.64 \\
\hline $\mathrm{F}$ & Pip H- $6 \beta$ & $4.53 \mathrm{~s}$ & $5.17 \mathrm{~s}$ & 0.64 \\
\hline
\end{tabular}

\footnotetext{
a See Fig. 3.
} 
Fig. 3. Conformation and ${ }^{1} \mathrm{H}$ NMR assignments of piperidine ring in thiopeptins $\mathrm{A}_{1 \mathrm{a}}$ and $\mathrm{A}_{1 \mathrm{~b}}$ in $\mathrm{CDCl}_{3}$ at $25^{\circ} \mathrm{C}$.

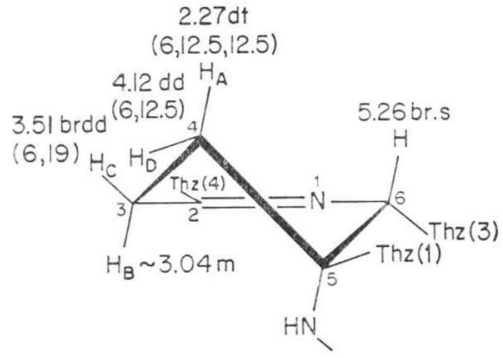

"b" Series $\left(A_{1 b}\right)$

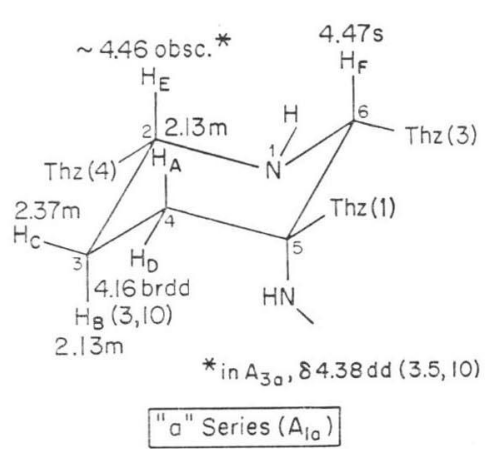

corresponding saturated piperidine ring system as characteristic of the a series. Moreover, by careful adjustment of temperature and concentration of TFA- $d$, the five spin system became approximately first order (see Table 8) which enabled the sequence of ring protons to be determined by double resonance. The results for the parallel assignments in $\mathrm{CDCl}_{3}$ are shown in Fig. 3. $\mathrm{H}_{\mathrm{E}}$ was chosen as the point of departure because of its unequivocal assignment to Pip $\mathrm{H}-2$ on the basis of its multiplicity and protonation shift. $\mathrm{H}_{\mathrm{E}}$ on irradiation was shown to be coupled to $\mathrm{H}_{\mathrm{C}}$ and either $\mathrm{H}_{\mathrm{A}}$ or $\mathrm{H}_{B}$ which overlap. The experiment was repeated in $\mathrm{CD}_{3} \mathrm{OD}-\mathrm{CDCl}_{3}(1: 9)$ containing $10 \%$ TFA- $d$ at $45^{\circ} \mathrm{C}$ (Table 8) in which one of the resonances, arbitrarily designated as $\mathrm{H}_{B}$, was shifted to lower field of $\mathrm{H}_{\Delta}$, leaving $\mathrm{H}_{\Delta}$ as a doublet of triplets. This is reminiscent of the multiplet structure for the high field resonance assigned to Pip H- $4 \beta$ in thiostrepton $A_{1}$ and $A_{2}$ and the $\mathbf{b}$ series of thiopeptins. Neither $H_{A}$ and $H_{D}$ were significantly affected which were thus assigned to the protons at $\mathrm{C} 4$ and $\mathrm{H}_{B}$ and $\mathrm{H}_{\mathrm{C}}$ at $\mathrm{C} 3$. The coupling of $H_{B}$ and $H_{C}$ to $H_{E}$ is first order and hence the splittings of the doublet of doublets for $\mathrm{H}_{\mathrm{E}}(3.5$ and $10 \mathrm{~Hz})$ reflect the true coupling constants. For a normal chair conformation of the piperidine ring, $\mathrm{H}_{E}$ is therefore axial and the thiazole ring at $\mathrm{C} 2$ equatorial. Irradiation of $\mathrm{H}_{\mathrm{E}}$ also established that $\mathrm{H}_{\mathrm{B}}$ is associated with the larger coupling constant and must therefore be axial. Irradiation of $\mathrm{H}_{\mathrm{D}}$ in the protonated medium collapsed $\mathrm{H}_{\mathrm{A}}$ from a doublet of triplets to a doublet of doublets where the splittings of 3.5 and $12.5 \mathrm{~Hz}$ only approximate the true vicinal coupling constants. $\mathrm{H}_{\mathrm{E}}$ remained unchanged whereas both $\mathrm{H}_{\mathrm{B}}$ and $\mathrm{H}_{\mathrm{C}}$ sharpened slightly as expected if $\mathrm{H}_{\mathrm{D}}$ is equatorial. The anomalous chemical shifts for $\mathrm{H}_{\mathrm{A}}$ and $\mathrm{H}_{\mathrm{D}}$ at $\mathrm{C} 4$ for corresponding members of both series are very similar as shown for thiopeptins $A_{1 \mathrm{a}}$ and $A_{1 b}$ in Fig. 3 and strongly argues for the same orientation of the protons to the thiazole and acylamino substituents at $C 5$. Moreover the almost identical chemical shifts of $H_{E}$ and $H_{F}$ in $A_{1 a}$ is consistent with the same orientation of the thiazole substituent at $\mathrm{C} 2$ and $\mathrm{C} 6$ which therefore completely defines the conformation and relative stereochemistry of the piperidine ring as in Fig. 3. The chair conformation maximizes the number of equatorial substituents and has the same relative stereochemistry at $\mathrm{C} 5$ and $\mathrm{C} 6$ as found in thiostrepton and the $\mathbf{b}$ series. Moreover the same absolute configuration at these centers would be expected on biogenetic grounds.

The question of absolute stereochemistry can be argued from a different viewpoint. It is evident from a comparison of the ${ }^{1} \mathrm{H}$ NMR data for both series of thiopeptins with that of thiostrepton that the overall conformation is very similar in solution which places strong conformational constraints on the orientation as well as configuration of ring substituents. Besides the same relative configuration at C5 
Table 9. ${ }^{13} \mathrm{C}$ NMR assignments of piperidine ring carbons in thiostrepton $\mathrm{A}_{1}$ and thiopeptins $\mathrm{A}_{1 \mathrm{a}}, \mathrm{A}_{1 \mathrm{~b}}$ and $\mathrm{B}_{\mathrm{a}}$ in $\mathrm{CD}_{3} \mathrm{OD}-\mathrm{CDCl}_{3}(1: 4)$ at $40^{\circ} \mathrm{C}$ and on protonation. ${ }^{\mathrm{a}}$

\begin{tabular}{ccrccc}
\hline & & \multicolumn{4}{c}{ Thiopeptin } \\
\cline { 3 - 6 } Assignment & Thiostrepton $\mathrm{A}_{1}$ & \multicolumn{1}{c}{$\mathrm{A}_{1 \mathrm{~b}}$} & $\mathrm{~A}_{1 \mathrm{a}}$ & $\mathrm{B}_{\mathrm{a}}$ & $\mathrm{B}_{\mathrm{a}}+6 \%$ TFA-d \\
& & $160.9 \mathrm{~s}$ & $56.8 \mathrm{~d}$ & 56.9 & $56.4 \mathrm{v} . \mathrm{br}$. \\
Pip C2 & 161.0 & $23.4 \mathrm{t}$ & $27.1 \mathrm{t}$ & 27.2 & $26.1 \mathrm{v} . \mathrm{br}$. \\
Pip C3 & 23.4 & $28.1 \mathrm{t}$ & $32.4 \mathrm{t}$ & 32.5 & $32.3 \mathrm{br}$. \\
Pip C4 & 27.9 & $56.4 \mathrm{~s}$ & $57.5 \mathrm{~s}$ & 57.6 & $57.7 \mathrm{br}$. \\
Pip C5 & 56.3 & $62.9 \mathrm{~d}$ & $60.7 \mathrm{~d}$ & 60.8 & $60.3 \mathrm{v} . \mathrm{br}$. \\
\hline
\end{tabular}

a In ppm downfield of TMS.

and $\mathrm{C} 6$ of the piperidine ring, the orientation of the substituents at these centers was found to be very similar in both series as shown in Fig. 3. The absolute configuration of all amino acid res dues from both series was found to be the same, i.e. L- for Ala, Thr and Val, and D- for Cys which provides convincing evidence for the same absolute configuration at $\mathrm{C} 5$ and $\mathrm{C} 6$ of the piperidine ring in both series which is thus completely defined as $2 R, 5 R, 6 R$.

Support for the saturated piperidine ring structure in the a series comes from ${ }^{13} \mathrm{C}$ NMR evidence. Comparison of the spectrum of thiopeptin $\mathrm{A}_{1 \mathrm{a}}$ with $\mathrm{A}_{1 \mathrm{~b}}$ (see Table 9) shows the presence of one additional resonance at $56.8 \mathrm{ppm}$ in the $45 \sim 80 \mathrm{ppm}$ region whereas the resonance assigned to the imine carbon at $160.9 \mathrm{ppm}$ in $\mathrm{A}_{1 \mathrm{~b}}$ is missing. Addition of TFA- $d$ to $\mathrm{B}_{\mathrm{a}}$ resulted in exchange broadening of the piperidine resonances but the same partial protonation shifts observed for the resonances at 56.9 and 60.8 ppm readily confirms their assignment as Pip C2 and C6 respectively.

The backbone of the bicyclic structure incorporates $\mathrm{C} 5$ and $\mathrm{C} 6$ of the piperidine ring and saturation of the N1-C2 double bond is expected to cause little change in the overall conformation of the molecule because of a minimal change in the relative orientations of the two thiazole and peptide substituents at these centers on proceeding from a half-chair to a chair conformation of the Pip ring (see Fig. 3). Only small chemical shift changes are observed for the neighboring Pip C5-NH and Ala (2) resonances between corresponding members of the $\mathbf{a}$ and $\mathbf{b}$ series (Table 2) which allows unequivocal assignment of the two Ala residues. This supports the assignment made on the basis of the thiostrepton crystal structure $^{2)}$ where Ala H-2 (2) lies in the deshielding cone of the dihydroquinoline ester carbonyl. The latter is therefore assigned to the resonance at lower field and assignments for the corresponding methyl and $\mathrm{NH}$ protons readily follow.

\section{Nature of Side Chain}

On the basis of our ${ }^{1} \mathrm{H}$ NMR study (see companion paper) it was proposed that the side chain of thiostrepton consists of two Deala residues confirming the ${ }^{18} \mathrm{C}$ NMR results of TorI et al. ${ }^{3)}$. Instead of the six doublets $(J=2.5 \mathrm{~Hz})$ characterizing the methylene protons of the three Deala residues in thiostrepton, of which one is located in the bicyclic portion of the molecule, thiopeptins $B_{a / b}$ and $A_{1 a / b}$ have four doublets coupled in pairs, in addition to two sharp singlets in the same region of the spectrum when examined in $\mathrm{CD}_{3} \mathrm{OD}-\mathrm{CDCl}_{3}(1: 4)$. In $\mathrm{CDCl}_{3}$ (Table 2), the upfield member of the two pairs, as for the three pairs in thiostrepton, occurs as a broad singlet which sharpens to a doublet on removal of the allylic coupling with the $\mathrm{NH}$ proton by either ${ }^{2} \mathrm{H}$-exchange or irradiation of the corresponding NH signal. It is known ${ }^{22)}$ that $J_{\text {gem }}$ of vinyl methylene protons is small and that the sign can be positive or negative depending largely on the electro-negativity of the substituent. Moreover, both sharp singlets and the NH singlet at $\delta 8.59$ in $\mathrm{A}_{1 \mathrm{a}}$ and $\mathrm{A}_{1 \mathrm{~b}}$ and $\delta 8.75$ in $\mathrm{B}_{\mathrm{a}}$, are missing in the spectrum of $\mathrm{A}_{4 \mathrm{a}}$ which 
implicates the terminal Deala residue having a modified amide group. Thiopeptin $\mathrm{B}_{\mathrm{a}}$ forms a sodium salt having characteristic bands in the infrared spectrum at 1610 and $1400 \mathrm{~cm}^{-1}$ and is therefore a carboxylic acid which readily accounts for its different chromatographic behavior from that of thiostrepton and the other thiopeptins. Besides its small Rf, thiopeptin $\mathrm{B}_{\mathrm{a}}$ 'tails' on silica gel TLC in methanol - methylene chloride (1:9) and is severely retarded on addition of ammonia to the solvent system. This is in sharp contrast to the considerably more mobile character of the other components (see Table 1) which form discrete spots and whose Rf's are unaffected by ammonia. The end groups of $A_{1 a}$ and $A_{1 b}$, because of the similar zero coupling between the methylene protons, must be of similar electro-negativity to that of the carboxyl group. Both compounds have a three proton singlet at $\delta 3.93$ and are therefore assigned as the methyl esters. Whereas thiopeptin $\mathrm{A}_{4 \mathrm{a}}$ has one Deala residue missing, thiopeptin $\mathbf{A}_{3 a}$ lacks two of the residues. As Deala residues are readily susceptible to hydrolysis ${ }^{17}{ }^{23)}$, it is not surprising therefore to find that both thiopeptin $B_{a}$ and $A_{1 a}$ give rise to thiopeptins $A_{4 a}$ and $A_{3 a}$ on acid hydrolysis with TFA and supports the proposal that thiopeptins $B_{a}$ and $A_{1 a}$ differ only in the nature of the side chain.

Confirmation of the proposed differences in the nature of the side chains comes from ${ }^{13} \mathrm{C}$ NMR evidence. Thiopeptin $\mathbf{B}_{\mathrm{a}}$ has 71 carbons whereas $\mathrm{A}_{1 \mathrm{a}}$ and $\mathrm{A}_{1 \mathrm{~b}}$ each have 72 , the extra resonance yielding a quartet at $51.5 \mathrm{ppm}$ on gated decoupling with ${ }^{1} J_{13 \mathrm{C}-\mathrm{H}}=148 \mathrm{~Hz}$ characteristic of a methyl ester. Thiopeptins $\mathrm{A}_{4 \mathrm{a}}$ and $\mathrm{A}_{3 \mathrm{a}}$ each have 68 and 65 carbons respectively, the missing carbons being readily assigned to two Deala residues on the basis of the assignments for the model compound 2-acetamido acrylic acid (see companion paper).

\section{Conclusion}

The total structure of all thiopeptin components proposed on the basis of ${ }^{1} \mathrm{H}$ and ${ }^{13} \mathrm{C}$ NMR evidence is shown in Fig. 1. They are closely related to thiostrepton and differ at four sites of the molecule. The presence of the thioamide group, which is responsible for the yellow color of the thiopeptins, is unique for a naturally occurring compound. ${ }^{24}$ ) Moreover, as for the corresponding amide group in thiostrepton, the thioamide has the $Z$ configuration. The mode of biosynthesis of the thiopeptide group is of interest as the structurally related antibiotic, nosiheptide ${ }^{4)}(=\text { multhiomycin })^{8}$ ) is also modified at this point having cysteine instead of threonine involved in a thioester linkage. The origin of the difference between the two series of thiopeptins lies solely in the nature of the piperidine ring, the $b$ series retaining the $\Delta^{1}$-piperidine moiety as in thiostrepton, while the a series are characterized by a fully saturated piperidine ring system. The evidence strongly supports the $\mathrm{D}$ configuration at the new asymmetric center Pip C2 in the a series, the same as at C4 and C6 in thiostrepton and the b series. A simple biosynthetic scheme incorporating $\alpha$-aminoadipic acid (Aad) for the formation of the pyridine ring in micrococcin $\mathbf{P}$ as proposed by WALKER et al. ${ }^{25}$ ) can also account for the piperidine ring in thiostrepton and the thiopeptins but with subsequent addition of a peptide amide at C5. Formally, the intermediacy of 2,5diamino adipic acid is suggested but its participation in secondary metabolism has never been shown. More recently BYCROFT ${ }^{26)}$ has suggested the intriguing possibility that its origin may be the result of the interaction of two Deala units in single peptide chain, but evidence for any of these proposed schemes has yet to be forthcoming. If in fact Aad is the biosynthetic precursor it will be of interest whether the $\mathrm{D}$ or $\mathrm{L}$ isomer is incorporated in light of the fact that the $\mathrm{D}$ configuration at Pip $\mathrm{C} 2$ is found, reminiscent of the presence of the $\mathrm{D}$ Aad side chain in the cephalosporins even though the $\mathrm{L}$ isomer is incorporated ${ }^{27}$. Biosynthetically, all four thiopeptin components $\mathbf{B}_{\mathrm{a} / \mathrm{b}}$ and $\mathrm{A}_{1 \mathrm{a} / \mathrm{b}}$ are simply related by an oxidation or reduction and hydrolysis or esterification sequence whereas the other components $\mathrm{A}_{4 \mathrm{a} / 4 \mathrm{~b}}$ and $\mathrm{A}_{8 \mathrm{a} / 3 \mathrm{~b}}$ were shown not to be true fermentation products but de-deala and bis-de-deala acid artifacts of thiopeptin $\mathrm{B}_{\mathrm{a} / \mathrm{b}}\left(\right.$ and $\left.\mathrm{A}_{1 \mathrm{a} / \mathrm{bb}}\right)$ respectively. 


\section{Experimental}

Infrared spectra were recorded in chloroform solution on a Perkin-Elmer 137 spectrometer and ultraviolet spectra in methanol on a Cary 15 instrument. ${ }^{1} \mathrm{H} \mathrm{NMR}$ at $300 \mathrm{MHz}$ and ${ }^{13} \mathrm{C}$ NMR at $75 \mathrm{MHz}$ were obtained using a Varian SC 300 instrument as previously described ${ }^{15}$. Low resolution mass spectra were obtained on a LKB 9000 and high resolution spectra on a Varian MAT-731 spectrometer. Analytical HPLC was performed on a Varian Model 4100 instrument.

\section{Isolation and Purification}

Fermentation broths were worked up similarly to the procedure of MiYAIRI et al. ${ }^{9}$. Dried mycelia from Merck and Fujisawa, obtained under a variety of fermentation conditions gave thiopeptin of variable composition and were extracted as follows:

Dried mycelia was extracted with $70 \%$ aqueous acetone overnight at room temperature and celite added to facilitate in filtration. After filtration, the mycelia was further washed with the same solvent and the filtrate concentrated. Prior to extraction with chloroform or ethyl acetate, the aqueous solution was saturated with $\mathrm{NaCl}$ to preven tformation of an emulsion. The chloroform layer was removed, concentrated to a small volume and added to five volumes of $n$-hexane to precipitate the crude thiopeptin. After sitting overnight at $0^{\circ} \mathrm{C}$ the precipitate was filtered off and dried. A typical procedure for the chromatographic separation of the thiopeptin components follows:

Thiopeptin $(8.5 \mathrm{~g})$ was dissolved in methanol - methylene chloride $\left(1: 19,+0.5 \% \mathrm{NH}_{3}, 170 \mathrm{ml}\right)$ and applied to the top of a column of silica gel 60 (E. Merck, $230 \sim 400$ mesh, $270 \mathrm{~g}, 51 \times 3.8 \mathrm{~cm}$ ). The column was eluted with the same solvent until the eluate became colored at which point $100 \mathrm{ml}$ fractions were collected and monitored by TLC on silica gel GF plates using the same solvent system. Only a trace of thiopeptin $A_{1 \mathrm{a}}$ was eluted in the first few fractions $(3 \times 100 \mathrm{ml})$ from this batch, after which thiopeptins $A_{8 \mathrm{a}}$ and $A_{4 a}$ began to emerge. Fraction 4 gave almost pure $A_{3 a}(0.75 \mathrm{~g})$ and subsequent fractions $(5 \times$ $100 \mathrm{ml}$ ) of chromatographically pure thiopeptin $\mathrm{A}_{4 \mathrm{a}}(1.42 \mathrm{~g})$ as pale yellow solids. Elution with methanol - methylene chloride $\left(1: 4,+2 \% \mathrm{NH}_{3}, 10 \times 100 \mathrm{ml}\right)$ gave thiopeptin $\mathrm{B}_{\mathrm{a}}(1.66 \mathrm{~g})$ which was rechromatographed on silica gel 60 to give pure thiopeptin $\mathrm{B}_{\mathrm{a}}$ as a pale yellow solid on evaporation of the solvent. UV and ${ }^{1} \mathrm{H}$ NMR (see text); IR $\left(\mathrm{CHCl}_{3}\right) \mu 3.0 \mathrm{vs}, 3.4 \mathrm{~s}, 5.75 \mathrm{~s}, 5.9 \mathrm{sh}, 6.05 \mathrm{vs}, 6.3 \mathrm{w}, 6.55 \mathrm{vs}$, $6.70 \mathrm{vs}, 6.90 \mathrm{~s}, 7.25 \mathrm{~m}, 7.65 \mathrm{w}, 7.8 \mathrm{~m}, 8.3 \mathrm{w}, 8.6 \mathrm{~m}, 8.8 \mathrm{~m}, 8.95 \mathrm{~m}, 9.1 \mathrm{~m}, 9.35 \mathrm{~m}, 9.75 \mathrm{w}, 9.9 \mathrm{w}, 10.45 \mathrm{w}$, $10.7 \mathrm{w}, 10.85 \mathrm{w}, 11.1 \mathrm{sh}$ and $11.25 \mathrm{~s}$.

Thiopeptin $\mathrm{A}_{3 \mathrm{a}}(0.74 \mathrm{~g})$ was rechromatographed on a silica gel $60(60 \mathrm{~g}, 36 \times 2.2 \mathrm{~cm})$ column and eluted with methanol - methylene chloride $\left(1: 19,+0.5 \% \mathrm{NH}_{3}, 6 \times 8 \mathrm{ml}\right)$ to give chromatographically pure thiopeptin $\mathrm{A}_{3 \mathrm{a}}(0.40 \mathrm{~g})$. The yellow solid was dissolved in $\mathrm{CHCl}_{3}$, centrifuged and the solid obtained after evaporation of the supernatant, recrystallized from tetrahydrofuran - ethyl acetate (1:3), giving clusters of fine needles at $-10^{\circ} \mathrm{C}$. The needles were collected and dried at $50^{\circ} \mathrm{C}$ for 24 hours for microanalysis resulting in a weight loss of $3 \%$. UV and ${ }^{1} \mathrm{H}$ NMR (see text). IR (see below).

Anal. Calcd. for $\mathrm{C}_{65} \mathrm{H}_{78} \mathrm{~N}_{17} \mathrm{O}_{15} \mathrm{~S}_{6} \cdot \mathrm{H}_{2} \mathrm{O}$ : C 50.41, $\mathrm{H}$ 5.27, N 15.37, S 12.42 .

Found:

C $50.84, \mathrm{H} 5.40, \mathrm{~N} 14.89, \mathrm{~S} 12.11$.

Various thiopeptin $\mathrm{A}_{1 \mathrm{~b}}$ fractions from different batches were pooled $(0.22 \mathrm{~g})$, dissolved in methanol methylene chloride $(1: 99)(6 \mathrm{ml})$ and filtered onto a column of silica gel $60(14 \times 1 \mathrm{~cm})$. The yellow band at the top of the column began to move and was eluted with methanol - methylene chloride (3: 97 , $7 \times 3 \mathrm{ml})$. Chromatographically pure thiopeptin $\mathrm{A}_{1 \mathrm{~b}}(0.11 \mathrm{~g})$ was obtained which crystallized from chloroform - ether $(2: 1)$ as yellow plates. A sample for microanalysis was dried at $50^{\circ} \mathrm{C}$ for 24 hours under high vacuum resulting in a $5.3 \%$ loss in weight. IR (see below).

Anal. Calcd. for $\mathrm{C}_{72} \mathrm{H}_{84} \mathrm{~N}_{18} \mathrm{O}_{18} \mathrm{~S}_{8} \cdot 4 \mathrm{H}_{2} \mathrm{O}$ : C 49.30, H 5.29, N 14.37, S 10.97. Found:

C 49.93, H 5.13, N 14.79, S 10.40 .

Similarly another batch yielded pure thiopeptin $\mathrm{A}_{1 \mathrm{a}}$ which recrystallized from ethyl acetate at $0^{\circ} \mathrm{C}$ as yellow plates.

Sodium Salt of Thiopeptin $\mathrm{B}_{\mathrm{a}}$

Thiopeptin $\mathrm{B}_{\mathrm{a}}(20 \mathrm{mg})$ was dissolved in tetrahydrofuran - methanol $(1: 1,20 \mathrm{ml})$ to which water $(1 \mathrm{ml})$ was added. The solution was chilled, acidified with a few drops of $1 \mathrm{~N} \mathrm{HCl}$ and quickly neutralized with $5 \%$ aqueous sodium bicarbonate with the addition of water or methanol to prevent the bicar- 
Table 10. Infrared differences for thiopeptin components $(\mu)$ in $\mathrm{CHCl}_{3}{ }^{\mathrm{a}}$.

\begin{tabular}{ccccc}
\hline $\mathrm{B}_{\mathrm{a}}$ & $\mathrm{A}_{1 \mathrm{a}}$ & $\mathrm{A}_{1 \mathrm{~b}}$ & $\mathrm{~A}_{4 \mathrm{a}}$ & $\mathrm{A}_{3 \mathrm{a}}$ \\
\hline- & - & - & $7.1 \mathrm{w}$ & - \\
- & $7.4 \mathrm{~s}$ & - & - & - \\
$10.45 \mathrm{w}$ & $10.45 \mathrm{w}$ & $10.1 \mathrm{w}$ & $10.5 \mathrm{w}$ & $10.5 \mathrm{w}$ \\
$10.7 \mathrm{w}$ & - & $10.65 \mathrm{~W}$ & - & - \\
$10.85 \mathrm{w}$ & $10.85 \mathrm{w}$ & $10.85 \mathrm{w}$ & $10.95 \mathrm{~m}$ & $10.9 \mathrm{w}$ \\
$11.1 \mathrm{sh}$ & $11.1 \mathrm{sh}$ & $11.1 \mathrm{sh}$ & - & $11.1 \mathrm{sh}$ \\
\hline
\end{tabular}

a) Intensities are abbreviated as $\mathrm{w}=$ weak, $\mathrm{m}=$ medium, $\mathrm{s}=$ strong, $\mathrm{vs}=$ very strong.

bonate or thiopeptin from precipitating. The final solution of $15 \mathrm{ml}$ was extracted with ethyl acetate three times and on evaporation yielded the sodium salt as a pale yellow solid. ${ }^{1} \mathrm{H}$ NMR: almost identical to that of thiopeptin $\mathrm{B}_{\mathrm{a}}$. IR $\left(\mathrm{CHCl}_{3}\right)$ same as for thiopeptin $\mathrm{B}_{\mathrm{a}}$ but with extra bands at 1620 sh and $1400 \mathrm{~cm}^{-1}$.

The IR of other thiopeptin components where different from that recorded for thiopeptin $B_{a}$ are summarized in Table 10.

Separation of Thiopeptin $\mathrm{B}_{\mathrm{a}}$ and $\mathrm{B}_{\mathrm{b}}$

${ }^{1} \mathrm{H}$ NMR analysis of thiopeptin $\mathrm{B}$ in $\mathrm{CD}_{3} \mathrm{OD}-\mathrm{CDCl}_{3}(1: 4)$ from various batches showed a mixture of the $\mathbf{a}$ and $\mathbf{b}$ components which was confirmed by HPLC on a $\mu$ Porasil column (Waters) using the solvent system methanol - methylene chloride $\left(1: 9,+1 \% \mathrm{NH}_{3}\right)$. A typical sample $(75 \mathrm{mg})$ having the ratio $B_{a} / B_{b}=1: 2$ was applied to 8 prewashed silicagel $H F$ plates (Analtech $20 \times 20 \times 0.025 \mathrm{~cm}$ ) and developed $(5 \times)$ with methanol - methylene chloride $\left(3: 17,+1 \% \mathrm{NH}_{3}\right)$. The band was divided into three sections and shown after elution to have the approximate $\mathrm{B}_{\mathrm{a}} / \mathrm{B}_{\mathrm{b}}$ ratios of $2: 1,1: 2$ and $1: 4$ (by ${ }^{1} \mathrm{H}$ NMR) in decreasing order of Rf. The mixture of lowest $R f$ having $B_{a} / B_{b}=1: 4$ was reapplied on 2 plates and multiply developed as before to give predominantly pure thiopeptin $\mathbf{B}_{b}$ as a pale yellow solid whose ${ }^{1} \mathrm{H}$ NMR is almost identical to that of thiostrepton $\mathrm{A}_{1 \mathrm{~b}}$ but with the absence of the $\mathrm{CH}_{3} \mathrm{O}$ singlet at $\delta$ 3.93 (see Table 2).

Acid Hydrolysis of Thiopeptin $\mathrm{B}_{\mathrm{a}}$

Thiopeptin was dissolved in trifluoroacetic acid and the time course of the hydrolysis followed by TLC on silica gel. The production of thiopeptins $A_{3 a}$ and $A_{4 a}$ was optimal between 3 to 4 hours at room temperature after which time several substances of lower $\mathrm{Rf}$ were formed. The products after separation by preparative TLC were shown by $\mathrm{Rf}$ and ${ }^{1} \mathrm{H}$ NMR to be identical with thiopeptin $\mathrm{A}_{\mathrm{a} a \mathrm{a}}$ and $\mathrm{A}_{4 \mathrm{a}}$.

Similarly thiopeptin $\mathrm{A}_{1 \mathrm{a}}$ was shown to give rise to $\mathrm{A}_{\mathrm{sa}}$ and $\mathrm{A}_{4 \mathrm{a}}$.

$\mathrm{NaBH}_{4}$ Reduction of Thiopeptin $\mathrm{A}_{1 \mathrm{~b}}$

Thiopeptin $\mathrm{A}_{1 \mathrm{~b}}(3.3 \mathrm{mg})$ was dissolved in methanol - methylene chloride (1:1,1 ml), chilled and $\mathrm{NaBH}_{4}(10.5 \mathrm{mg})$ added. The mixture was gently stirred for 3.5 hours, more $\mathrm{NaBH}_{4}(5 \mathrm{mg})$ added and allowed to react for a further 2.5 hours at room temperature. The $\mathrm{pH}$ was adjusted to 4.0 with concentrated $\mathrm{HCl}$ using $\mathrm{pH}$ paper, the mixture evaporated to dryness and the residue hydrolyzed with conc. $\mathrm{HCl}$ and subjected to amino acid analysis (see Table 1).

Amino Acid Analysis

Analyses on hydrolysates ( $6 \mathrm{~N} \mathrm{HCl}$ for 20 hours) were performed on a Beckman Model $121 \mathrm{MH}$ amino acid analyzer. The amino acids Thr, Val and Ala obtained on hydrolysis of the thiopeptin components were all shown to have the L-configuration and Cys the D-configuration by the MANNINGMOORE procedure ${ }^{29}$.

\section{Acknowledgments}

We wish to thank the Fujisawa Pharmaceutical Co., Japan and the Department of Developmental Microbiology (Merck) for samples of thiopeptin mixture, Mr. CARL HoMNICK for performing the amino acid analyses and Mr. JACK SMITH and Dr. JeRrold Liesch for mass spectral data. 


\section{References}

1) Berdy, J.: Recent developments of antibiotic research and classification of antibiotics according to chemical structure. Adv. Appl. Microbiol. 18: 309 406, 1974

2) Anderson, B.; D. C. Hodgkin \& M. W. Viswamitra: The structure of thiostrepton. Nature (London) 225: $233 \sim 235,1970$

3) Tori, K.; K. Tokura, K. Okabe, M. Ebata, H. Otsuka \& G. Lukacs: Carbon-13 NMR studies of peptide antibiotics, thiostrepton and siomycin: the structure relationship. Tetrahedron Lett. 1976: 185 188, 1976

4) Pascard, C.; A. Ducruix, J. Lunel \& T. Prange: Highly modified cysteine-containing antibiotics. Chemical structure and configuration of nosiheptide. J. Am. Chem. Soc. 99: 6418 6423, 1977

5) Kirst, H. A.; E. F. Szymanski, D. E. Dorman, J. L. Occolowitz, N. D. Jones, M. O. Chaney, R. L. Hamill \& M. M. Hoenn: Structure of althiomycin. J. Antibiotics 28: 286 291, 1975

Sakakibara, H.; H. Naganawa, M. Ohno, K. Maeda \& H. Umezawa: The structure of althiomycin. J. Antibiotics 27: 897 899, 1974

6) Liesch, J. M. \& K. L. Rinehart, Jr.: Berninamycin. 3. Total structure of berninamycin A. J. Am. Chem. Soc. 99: 1645 1646, 1977 and references therein

7) Walker, J.; A. Olesker, L. Valente, R. Rabanal \& G. Lukacs: Total structure of the poly-thiazolecontaining antibiotic micrococcin P. A ${ }^{19} \mathrm{C}$ nuclear magnetic resonance study. J. Chem. Soc., Chem. Commun. 1977: 706 708, 1977

ByCROFt, B. W. \& M. S. Gowland: The structures of the highly modified peptide antibiotics micrococcin $\mathrm{P}_{1}$ and $\mathrm{P}_{2}$. J. Chem. Soc., Chem. Commun. 1978: 256 258, 1978

8) Endo, T. \& H. Yonehara: Identity of multhiomycin with nosiheptide. J. Antibiotics 31: 623 625, 1978

9) Miyairi, N.; T. Miyoshi, H. Aoki, M. Kohsaka, H. Ikushima, K. Kunugita, H. Sakai \& H. Imanaka: Thiopeptin, a new feed additive antibiotic: microbiological and chemical studies. Antimicrob. Agents Chemother. 1: 192 196, 1971

10) Wang, C. C. \& S. S. Pong: Private communication

11) Mine, K.; N. Miyairi, N. Takano, S. Mori \& N. Watanabe: Thiopeptin, a new feed-additive antibiotic: Biological studies and field trials. Antimicrob. Chemother. 1: 496 503, 1972

12) Muir, L. A. \& A. Barreto: U. S. Patent 4,061,732, 1977

13) Miyairi, N.; T. Miyoshi, H. Aoki, M. Kohsaka, H. Ikushima, K. Kunugita, H. Sakai \& H. Imanaka: Studies on thiopeptin antibiotics. I. Characteristics of thiopeptin B. J. Antibiotics 23: 113 119, 1970

14) Muramatsu, I.; E. Hikawa, A. Hagitani \& N. Miyairi: Quinoline derivatives as degradation products from antibiotic thiopeptin B. J. Antibiotics 25: 537 538, 1972

Muramatsu, I.; Y. Motoki, M. Aoyama \& H. Suzuki: Amino acids and derivatives of thiazole-4-carboxylic acid as constituents of thiopeptin B. J. Antibiotics 30: 383 387, 1977

15) A preliminary communication of this work has appeared. Hensens, O. D. \& G. Albers-SCHÖNBERG: Total structure of the peptide antibiotic components of thiopeptin by ${ }^{1} \mathrm{H}$ and ${ }^{13} \mathrm{C}$ NMR spectroscopy. Tetrahedron Lett. 1978: 3649 3652, 1978

16) Bodanszky, M.; J. Fried, J. T. Sheehan, N. J. Williams, J. Alicino, A. I. Cohen, B. T. Keeler \& C. A. BIRkHIMER: Thiostrepton. Degradation products and structural features. J. Am. Chem. Soc. 86: 2478 2490, 1964

17) Bodanszky, M.; J. A. Scozzie \& I. Muramatsu: Dehydroalanine residues in thiostrepton. J. Antibiotics 23: $9 \sim 12,1970$

18) Footnote 7 in reference 15

19) Kalinowski, H. O. \& H. Kessler: Correlation of the ${ }^{13} \mathrm{C}$ NMR chemical shifts of carbonyl and thiocarbonyl groups. Angew. Chem. Intern. Ed. Engl. 13: 90 91, 1974

20) Walter, W.; E. Schaumann \& H. Paulsen: Zur magnetischen Anisotropie der Thioamid-Gruppe. Justus Liebigs Ann. Chem. 727: 61 70, 1969

21) Roussel, R.; A. Liden, M. Chanon, J. Metzger \& J. Sandström: The gear effect. V. A model for conformational transmission. J. Am. Chem. Soc. 98: 2847 2852, 1976

22) Jackman, L. M. \& S. Sternhell: Applications of Nuclear Magnetic Resonance Spectroscopy in Organic Chemistry. 2nd ed., Pergamon Press, Oxford, p. 279, 1969

23) Liesch, J. M.; D. S. Millington, R. C. Pandey \& K. L. Rinehart, Jr.: Berninamycin. 2. Products of acidic hydrolysis, methanolysis, and acetolysis of berninamycin A. J. Am. Chem. Soc. 98: 8237, 1976

24) Walter, W. \& J. Voss: The chemistry of thioamides. In J. ZaBicky, Ed., The Chemistry of Amides. pp. $383 \sim 475$, Interscience Publishers, London, 1970

25) Hall, G. E.; N. Sheppard \& J. Walker: Chemistry of micrococcin P. X. Proton magnetic resonance 
spectrum of dimethyl micrococcinate, and the probable mode of biosynthesis of micrococcinic acid. J. Chem. Soc. (C) 1966: 1371 1373, 1966

26) Bycroft, B. W. \& M. S. Gowland: The structures of the highly modified peptide antibiotics micrococcin $\mathrm{P}_{1}$ and $\mathrm{P}_{2}$. J. Chem. Soc., Chem. Commun. 1978: 256 258, 1978

27) Lemke, A. A. \& D. R. BRAnnon: Microbial synthesis of cephalosporin and penicillin compounds. In E. H. Flynn, Ed., Cephalosporins and Penicillin. pp. 370 437, Academic Press, New York, N. Y., 1972

28) Manning, J. M. \& S. Moore: Determination of D- and L-amino acids by ion exchange chromatography as L-D and L-L dipeptides. J. Biol. Chem. 243: 5591 5597, 1968 